\title{
DETERMINATION OF THE MOST SUITABLE ECOTOURISM ACTIVITIES WITH THE ANALYTIC HIERARCHY PROCESS: A CASE STUDY OF BALAMBA NATURAL PARK, TURKEY
}

\author{
ÇELIK, D.
Programme of Landscape and Ornamental Plants, Vocational High School, Bartın University 74100 Bartin, Turkey
(e-mail:dcelik@bartin.edu.tr; phone: +90-378-227-9939/147; fax: +90-378-227-8875)

(Received 29 $9^{\text {th }}$ Mar 2018; accepted $12^{\text {th }}$ Jun 2018)

\begin{abstract}
Ecotourism can be defined as tourism conserving the existing natural and socio-cultural structure, considering the balance between conservation and utilization, promoting the sustainability of natural resources, encouraging tourism activities, and developing the economic structure of the local community. Natural parks are areas where local and foreign tourists may join ecotourism activities due to their natural and cultural landscape potentials. Balamba Natural Park (BNP) located in the city of Bartin in Turkey, was chosen as a research area due to its natural landscape values and easy accessibility. The research method is composed of the following steps; data acquirement, field analysis, Analytical Hierarchy Process (AHS), Strengths, Weaknesses, Opportunities, and Threats (SWOT) Analysis, evaluation of findings, and conclusion and recommendations. This study aimed to determine the most suitable ecotourism activities in the existing potentials BNP. As a result, the study concluded that ecotourism activities such as botanical tourism, trekking, photo safaris, bicycle safaris and bird/butterfly watching could be implemented in the BNP.
\end{abstract}

Keywords: natural and cultural landscape, nature conservation, land use, collaborative planning, Bartin

\section{Introduction}

According to Hector Ceballos-Lascurain, ecotourism is a sightseeing tour of flora and fauna for touristic purposes and for observance and monitoring of cultural activities in natural areas that have not been interfered with by human beings (Cheia, 2013). This definition of ecotourism has recently become even more comprehensive. Ecotourism can be defined as responsible travel aimed at promoting the expansion of conservation awareness among both tourists and local residents, as well as conserving natural and cultural areas, maintaining sustainability, and raising the economic level of local communities (Gössling, 1999; Ceylan, 2004; Kuvan and Akan, 2005; Jaafar and Maideen, 2012; ESTA, 2016; Wishitemia et al., 2015; Verdugo et al., 2016; TIES, 2017). Briefly, the definition of ecotourism includes fundamental issues/characteristics such as natural and cultural areas, conservation, benefits for local residents, education, sustainability, ethics and awareness (Fennell, 2001).

With flora-fauna richness, aesthetic and natural beauty, water resources, active and passive recreational opportunities, the natural conservation areas and forests, where ecotourism activities are realized, have several potentials (Toskay, 1989). Ecotourism activities have several influences on the natural and cultural environment. However, the negative effect of these activities are at the lowest level, and the positive effects are at the highest level (Nyaupane and Thapa, 2004). In addition, ecotourism activities may contribute to the conservation of natural resources by providing economic support in this manner (Lopez and Monteros, 2002). Ecotourism may also accommodate several nature-based activities. Botanical tourism, mountain tourism, photo safaris, wildlife observation, cave tourism, adventure tourism, boating, and walking through forests or in 
nature could be provided as examples. Furthermore, cultural tourism activities are also included within ecotourism activities (Erdoğan, 2003; Hussin et al., 2015).

There are various activities related to ecotourism in Turkey. For example, with the aim to develop ecotourism, the improvement of protected wildlife reserves, national parks and similar conservation areas and activities related to the protection of natural, cultural and aesthetic values, were included in the Five-Year Development Plans (EFYDP, 2000). In addition, ecotourism sites and the Tourism Strategies of Turkey were identified by the Ministry of Culture and Tourism, and the importance of issues such as sustainable use of natural and cultural resources and increasing the level of social consciousness and awareness were emphasized (TTS2023, 2007; EPD, 2017). In Turkey, as is the case in many countries, the national parks, protected wildlife reserves, etc., have been mostly utilized for ecotourism purposes (ESR, 2012). The definition of a natural park, from a legal dimension, was established with Turkey's National Parks Law No. 2873, and the authorized organizations were determined in this field (NPL, 2016.). According to the 2018 official data provided by the General Directorate of Nature Conservation and National Parks within the Ministry of Forestry and Water Affairs, there are 214 natural parks in our country (PA, 2018). Indeed, one of these parks is Balamba Natural Park. In terms of landscape potentials, BNP has the power to be an important centre of attraction in Bartın Province and the immediate surrounding areas. Therefore, the purpose of this study was to attain answers to the following questions: what are the existing landscape potentials of BNP? And, what are the most suitable ecotourism activities to utilize these potentials? This study also foresaw that any activities held in BNP should be assessed within the scope of ecotourism in terms of not harming nature, ensuring environmental sustainability, and providing economic benefits to the local community.

\section{Material and methods}

\section{Study area}

The main material in the study was BNP itself. BNP was located at $41^{\circ} 37^{\prime} 39.62^{\prime \prime} \mathrm{N}$ and $32^{\circ} 21^{\prime} 47.59^{\prime \prime}$ E. Based on the 1/5000 scale master plan, there were residential areas in the southern and north-western areas in BNP and agricultural lands in the northern and eastern areas. The park covered an area of 13,105 ha. BNP was located in the eastern side of the central district in Bartın Province, at a distance of $2.2 \mathrm{~km}$ from the city centre, and on the Bartın-Karabuk Highway (Fig. 1). The park was located at an altitude of $13-30 \mathrm{~m}$. Approximately $31.5 \%$ of the park had north-east-facing slopes, and $30 \%$ was considered to be within the range of the 10-20\% slope group. It is located within the first degree earthquake zone. The First Revision Development Plan for the park was created in 2006. In this context, the Plan was aimed at protecting the natural resources and recreational potential of the area, developing without destroying the existing values, and ensuring sustainable development (Anonymous, 2006). While the Park Balamba was once used as an in-forest-recreational-ground, the land was converted from this status into a natural park, in accordance with the provisions from Article 3 of the National Parks Law No. 2873, dated 11.07.2011 (BNP, 2017).

Since BNP was located in Bartın city centre, it was selected as a research area and had a landscape potential to serve the communities in the city and in the immediate surrounding areas and also presented high local recognition and accessibility. In addition, this park was located in Bartın Province, which was previously selected for its 
potential in terms of biological diversity and ecotourism development in the Black Sea Region within the scope of Turkey's Tourism Strategy, 2023 (TTS2023, 2007).

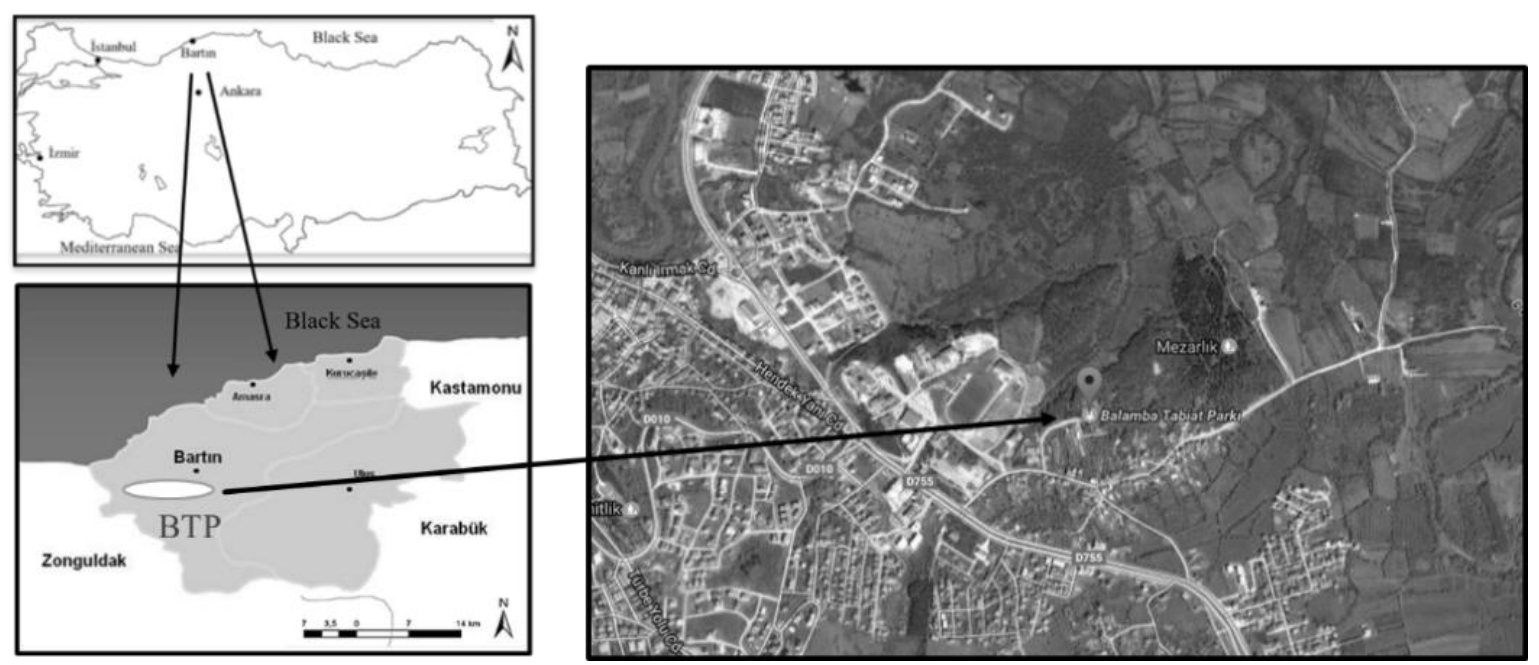

Figure 1. Maps of the location of Bartin Province and BNP

\section{Methods}

The methods in this research were developed by analysing studies in the literature (Saaty, 1994; Akpınar, 1995; Scholl, 2005; Timor, 2011; Akpınar Külekçi and Bulut, 2013; Y1lmaz and Surat, 2015). The research was conducted within a six-stage method. These stages included literature review and data retrieval; land analysis and observation; administration of a questionnaire using AHP with the participation of experts among the relevant stakeholders; a SWOT (Strengths, Weaknesses Opportunities, Threats) analysis; evaluation of findings; and the conclusion and recommendations.

In the first stage, a national and international literature review was conducted on the topics of natural parks, AHP, BNP, ecotourism, etc., and the necessary required data were obtained through interviews at the related institutions and organizations. In the second stage, field analyses and observations were performed, and the current situation was determined by taking photographs when visiting the area of interest during different seasons.

In the third stage, a public survey was conducted by interviewing the stakeholders and experts who were considered relevant, such as representatives from the Bartin Provincial Directorate of Forestry and Water Affairs, Bartın Provincial Directorate of Culture and Tourism, Kure Mountains National Park Directorate, Bartın Municipality, Bartın University, Bartın Provincial Directorate of Environment and Urbanism, Bartın Provincial Representative of the Chamber of Landscape Architects, the Grand Astra Hotel (tourism enterprise) and a specialized tour agency. A total of nine experts participated in the questionnaire, including various professionals such as a landscape architect, forest engineer, art historian, archaeologist, construction engineer, tourism operator, botanist, and wilderness guide. The questionnaire made it possible to determine the most suitable ecotourism activity among the potential activities. Questionnaires were conducted by the author using the AHP method in June 2017. The AHP method was used for the ranking process and selecting the alternatives in accordance with multiple criteria. Questionnaires were administered to more specialized 
persons. In the fields of sensitive areas, education, health, planning, tourism, architecture, etc., the most suitable location, ecotourism activity, and selection of project or education methods, etc., were available for use by different professional disciplines (Saaty, 1977; Akpınar, 1995; Saaty and Vargas, 2006; Akten et al., 2009; Daşdemir and Güngör, 2010; Akpınar Külekçi and Bulut, 2012; Medjoudj et al., 2012; İmren et al., 2017; Chen et al., 2014; Y1lmaz and Surat, 2015). In addition, with the use of the AHP method together with GIS (Geographic Information System), selection of the most suitable area can be achieved for planning green spaces in urban areas, selection of the most suitable solid waste area, and determination of the most suitable marina location, etc. (Lin et al., 2008; Gumusay et al., 2016; Şener et al., 2011).

The AHP method, developed by Saaty, allows us to use both qualitative and quantitative attributes. In the AHP, the factors within the scope of the goal and the subfactors belonging to these key factors are determined first. Thus, the AHP decision hierarchy is established (Scholl, 2005). Subsequently, a binary comparison is made between the factors. The significance level or weights of the factors are determined. The consistency rate (CR) of the questionnaires is checked. If the CR is less than 0.10, the identified values are considered valid and acceptable (Saaty, 1994; Akpinar, 1995; Timor, 2011).

During the fourth stage, a SWOT analysis of the area was conducted based on the results of the field analyses, observation, the questionnaire data and literature review. SWOT analysis is a method used to determine the strengths and weaknesses of the studied environment, organization, technique, city, period, etc., and to identify opportunities and threats originating from internal and external environments. The objective of this technique is to develop strategies to obtain the maximum benefit from the strengths and opportunities available and to reduce the effect of the weaknesses and keep threats to a minimum. While the strengths and opportunities have a positive effect; the weaknesses and threats result in a negative effect. There are strong and weak aspects, which may be mostly under our control, in the internal environment. However, the external environment contains opportunities and threats, which are factors usually outside of our control. The possibilities to convert weaknesses, such as political, economic, sociocultural, and technological factors, into strengths have been carried out via SWOT analysis, and efforts are underway to remove the threats (Gürlek, 2002). SWOT analysis is also used for determining the current state and development of strategies on issues such as tourism, utilization of natural resources, sustainable development, conservation areas, and the energy and economic sectors (Ghinolfi et al., 2014; Scolozzi et al., 2014; Ghorbani et al., 2015; Açıksöz et al., 2016; Njoh, 2017).

In the fifth stage, the findings were analysed and evaluated from the perspective of the discipline of the landscape architecture profession by relating the findings to issues such as ecotourism and collaborative planning. In the sixth stage, however, the obtained results regarding the most suitable ecotourism activities for the existing potential were presented, and recommendations were formed.

\section{Results}

\section{The current field usage}

The current situation of the BNP was determined by field studies and observations. The park is under the influence of both the Black Sea climate, which is hot in summer and cool in winter seasons, and a forest ecosystem. The BNP is entered by a single 
access point. At this entrance, there are fees for vehicles and visitors. In the entrance area, there are a parking lot, a water-well, a rural-casino, an amphitheater, a information desk, a basketball court, children's playgrounds, and pergolas. There are also 40 picnic tables, 30 barbecues and 6 fountains that are located in suitable places throughout the area. The 2-meters-wide walking trail and 1153-m-long and 4-m-wide existing forest road, of which both were decided in the $1^{\text {st }}$ Revision of the BNP Development Plan, are still in use at the present time. There are tennis courts and areas for fitness equipment on the walking trail. In the park, there are also four natural water channels for drainage, especially for the rainy periods against rain falls. Bridges are constructed for passing over these water channels. Today, the use of park continues as a picnic area and walking area, and as well as photographing area for weddings.

\section{Questionnaire results}

Using the AHP method with the expert group, a questionnaire was conducted to determine the ecotourism activity that best suits the current landscape potentials of BNP. The AHP full-hierarchy model generated for BNP is shown in Figure 2.

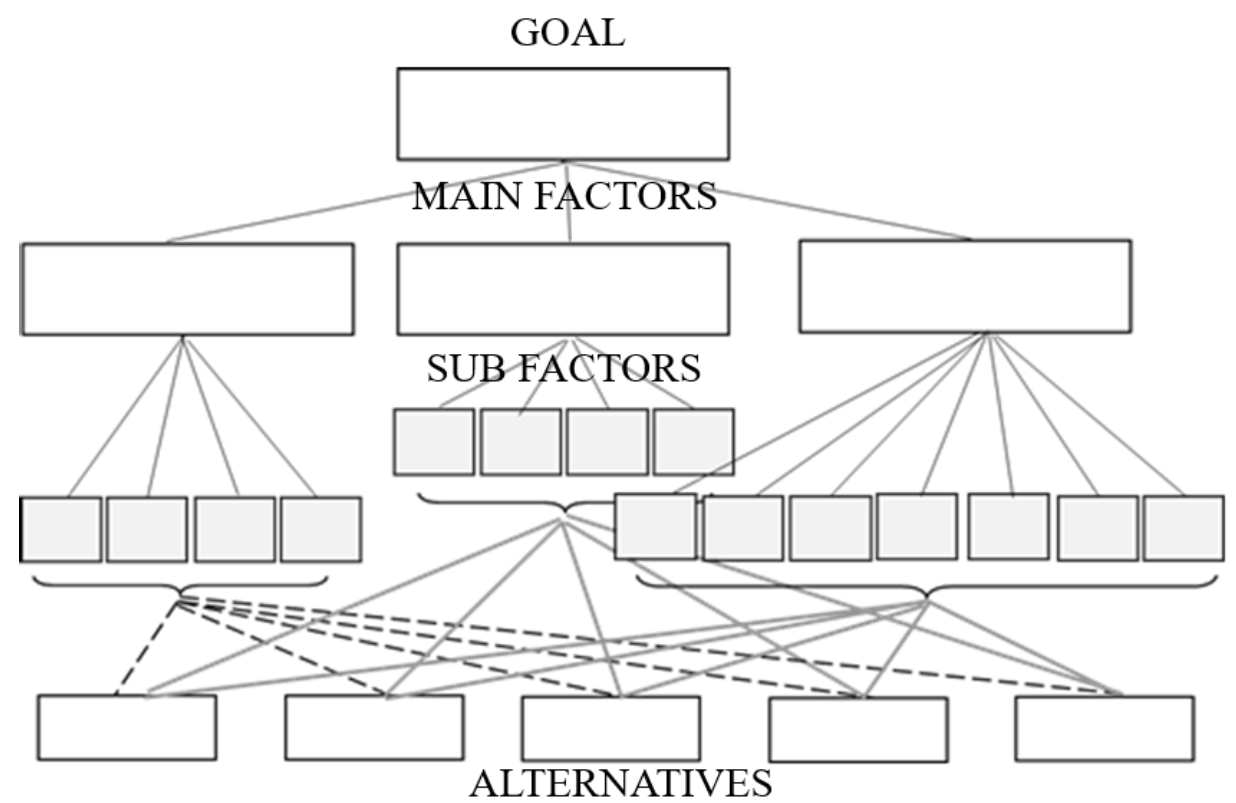

Figure 2. Full AHP Hierarchy modes for BNP

The purpose of this questionnaire was to make a classification between the main factors, sub-factors, and alternatives. For this purpose, 19 questions containing the key factors, sub-factors and alternatives were asked to the experts. The natural and cultural landscaping potentials were considered when determining the main factors and subfactors. These factors were identified based on the literature review (Akpinar, 1995; Akten et al., 2009) performed on BNP-related studies and field analyses. While the main factors were composed of 3 variables, the sub-factors consisted of 15 variables, and the alternatives included 5 variables. The main factors consisted of the following variables: natural factors, socio-cultural and economic factors, and factors related to targets and policies regarding land usage. The main factors, sub-factors and alternatives are presented in Table 1. 
The Expert Choice (EC) software program was utilized for calculations and use of the AHP method. When the data obtained from the AHP were analysed, binary comparisons were also performed between the main factors and sub-factors. By using this program, the significance levels and weights of the factors, as well as the weight scores of the alternatives/ecotourism activities for each factor were determined. The questionnaires were determined to be meaningful since their consistency rates were identified as below 0.1. In addition, sensitivity analysis was also performed on the main factors. The survey results via use of the AHP are summarized below.

Table 1. Main factors, sub-factors and alternatives used in the questionnaire

\begin{tabular}{|c|c|c|}
\hline Main factors & Sub-factors & Alternatives \\
\hline \multirow{4}{*}{ Natural Factors (NF) } & Climate & \multirow{15}{*}{$\begin{array}{ll}\text { - } & \text { Botanical tourism } \\
\text { - } & \text { Trekking } \\
\text { - } & \text { Bird/butterfly watching } \\
\text { - } & \text { Photo safari } \\
\text { - } & \text { Bicycle safari }\end{array}$} \\
\hline & Flora/fauna & \\
\hline & Topography & \\
\hline & Geographical location & \\
\hline \multirow{4}{*}{$\begin{array}{l}\text { Socio-cultural and economic factors } \\
\text { (SCEF) }\end{array}$} & Transportation & \\
\hline & Economic status of visitors & \\
\hline & $\begin{array}{l}\text { Demographic structure of } \\
\text { visitors }\end{array}$ & \\
\hline & $\begin{array}{c}\text { Existence of nearby attraction } \\
\text { centres }\end{array}$ & \\
\hline \multirow{7}{*}{$\begin{array}{l}\text { Factors related to land use targets and } \\
\text { policies (FRLUTP) }\end{array}$} & Biodiversity conservation & \\
\hline & $\begin{array}{c}\text { Satisfaction of recreational } \\
\text { needs }\end{array}$ & \\
\hline & $\begin{array}{l}\text { Preservation of visual } \\
\text { landscape potentials }\end{array}$ & \\
\hline & City branding & \\
\hline & $\begin{array}{l}\text { Diversification of tourism } \\
\text { activities }\end{array}$ & \\
\hline & $\begin{array}{l}\text { Increase in business } \\
\text { opportunities }\end{array}$ & \\
\hline & Improvement of infrastructure & \\
\hline
\end{tabular}

For the binary comparison between the factors, experts were asked to generate an assessment in accordance with the basic scale listed in Table 2.

Table 2. The significance levels and their definitions used in the binary comparison among criteria (Saaty and Vargas, 2006)

\begin{tabular}{c|c}
\hline Significance level & Definition \\
\hline 1 & Equal importance \\
3 & Moderate importance \\
5 & Strong importance \\
7 & Very strong importance \\
9 & Extreme importance \\
$2,4,6,8$ & Intermediate levels \\
\hline
\end{tabular}




$$
-4335-
$$

Based on the existing potentials, which were obtained from the experts, a binary comparison matrix, in which each main factor was compared with the others for determination of the most suitable ecotourism activities, is presented in Table 3.

Table 3. The binary comparison matrix of the main factors

\begin{tabular}{c|c|c|c}
\hline & NF & SCEF & FRLUTP \\
\hline NF & 1 & 4 & 3 \\
\hline SCEF & $1 / 4$ & 1 & $1 / 2$ \\
\hline FRLUTP & $1 / 3$ & 2 & 1 \\
\hline
\end{tabular}

In Table 3, factors in rows were compared to factors in columns. These comparisons were presented as questions in the questionnaire form. The natural factors were scored with 4 points when compared to the sociocultural and economic factors and 3 points when compared to the factors related to targets and policies for land usage. In this case, the natural factors had priority for significance at the outset.

According to Figure 3, when the main factors, which were assumed to be effective for selecting the ecotourism activities by experts, were classified based on their weight ratios, 'natural factors' was ranked as the factor with the highest weight ratio (0.625).

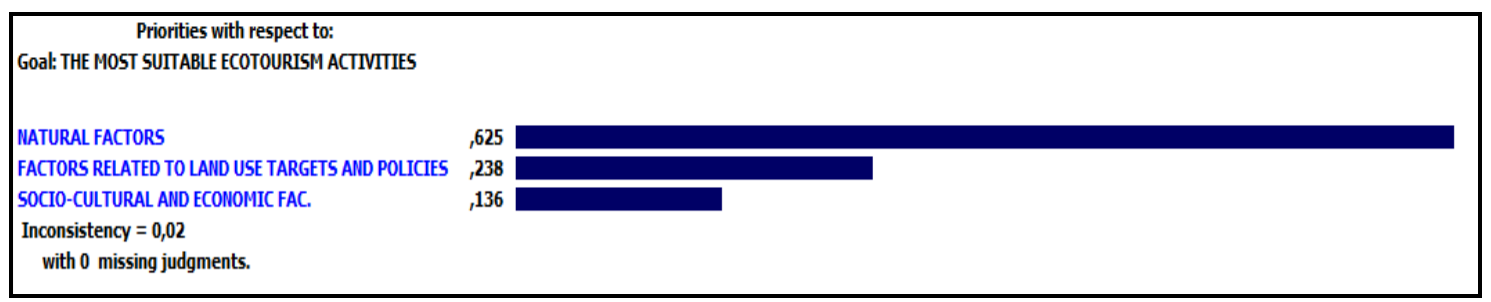

Figure 3. The weight ratios for the main factors

The sub-factor of flora/fauna was rated with the highest score by the experts. The binary comparisons among the sub-factors of the natural factors are also shown in Figure 4. According to Figure 4, the significance levels of the sub-factors of the natural factors were ranked as follows: flora/fauna, climate, topography, and geographical location.

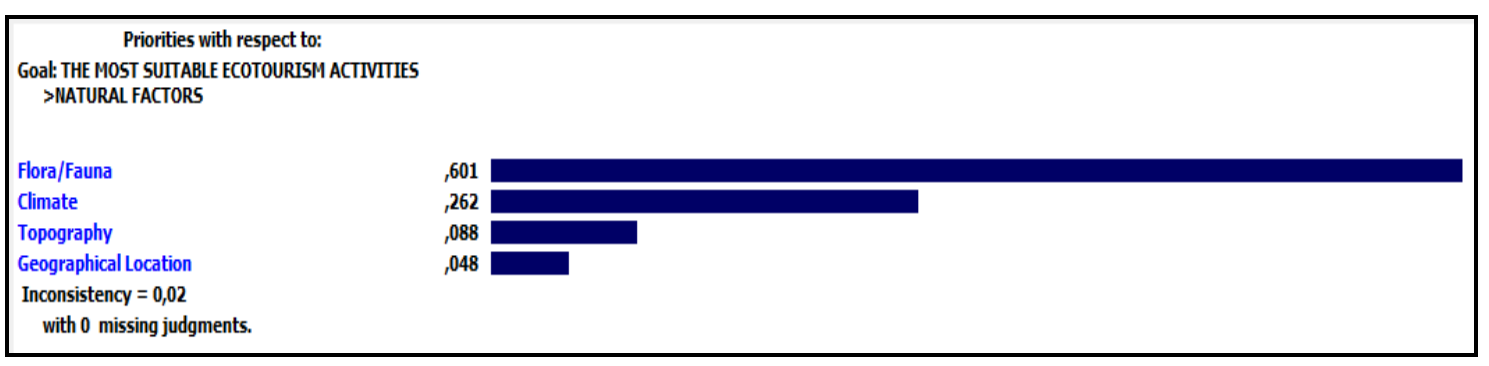

Figure 4. The weight ratios of the sub-factors related to natural factors

As a result of the binary comparison of natural factors with alternatives, botanic tourism had the highest weight ratio (0.338) (Fig. 5). 


\begin{tabular}{|l|l|}
\hline Goal: THE MOST SUITABLE ECOTOURISM ACTIVITIES & Botanical tourism \\
\hline NATURAL FACTORS (L: ,625 G: ,625)] & Trekking \\
\hline Climate (L: ,262 G: ,164) & Bird/butterfly watching \\
Flora/Fauna (L: ,601 G: ,376) & Photo safari \\
& Bicycle safari \\
Topography (L: ,088 G: ,055) & \\
Geographical Location (L: ,048 G: ,030) & .110 \\
\hline SOCIO-CULTURAL AND ECONOMIC FACTORS (L: ,136 G: ,136) & .225 \\
\hline FACTORS RELATED TO LAND USE TARGETS AND POLCIES (L: ,238 G: , 238) & \\
\hline
\end{tabular}

Figure 5. The weight ratios of the ecotourism activities based on the natural factors

Trekking had the highest weight ratio based on the binary comparison of climate and topography sub-factors with alternatives. When the flora/fauna and geographical location sub-factors were compared with alternatives, however, botanical tourism received the highest weight ratio.

The sub-factor of transportation was rated with the highest score (weight ratio 0.542) by the experts. According to Figure 6 the significance levels of the sub-factors belonging to the socio-cultural and economic factors were ranked as follows: transportation, demographic structure of visitors, existence of nearby attraction centres, and economic status of visitors.

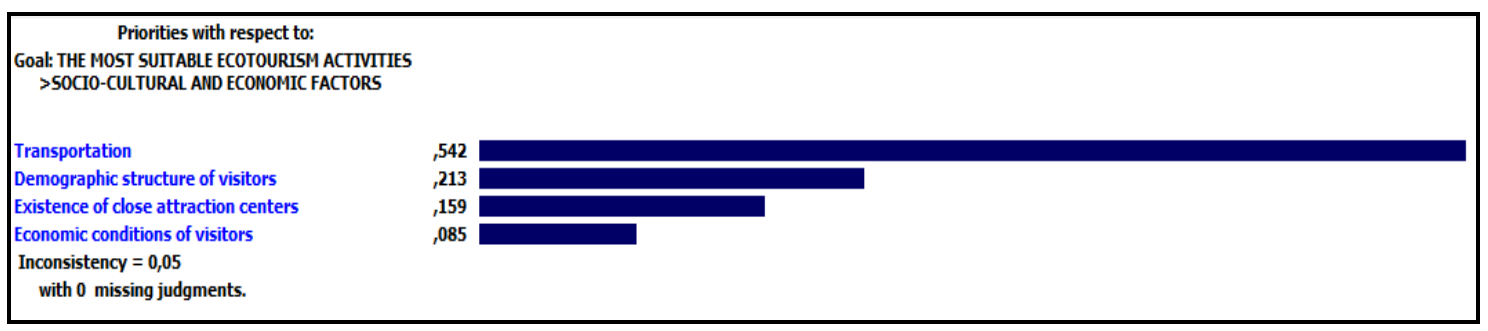

Figure 6. The weight ratios of the sub-factors related to socio-cultural and economic factors

As a result of the binary comparison of socio-cultural and economic factors with alternatives, trekking was identified as the highest weight ratio (0.507) (Fig. 7).

\begin{tabular}{|c|c|c|}
\hline 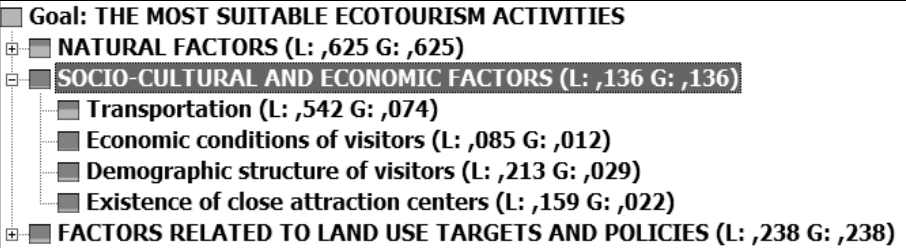 & \begin{tabular}{|l} 
Botanical tourism \\
Trekking \\
Bird/butterfly watching \\
Photo safari \\
Bicycle safari \\
\end{tabular} & $\begin{array}{l}.158 \\
.507 \\
.065 \\
.142 \\
.128\end{array}$ \\
\hline
\end{tabular}

Figure 7. The weight ratios of the ecotourism activities based on the socio-cultural and economic factors

The binary comparison of alternatives with sub-factors, such as transportation, economic status of visitors, demographic structure of visitors, and the existence of nearby attraction centres, resulted in the identification of trekking as the activity with the highest weight ratio.

The binary comparison among the sub-factors of the main factor related to land use targets and policies is shown in Figure 8. The sub-factor of conservation of biodiversity was rated with the highest score $(0.401)$ by the experts. Others were ranked in the 
following order: diversification of tourism activities, city branding, improvement of infrastructure, preservation of visual landscape potentials, increase in business opportunities, and satisfaction of recreational needs.

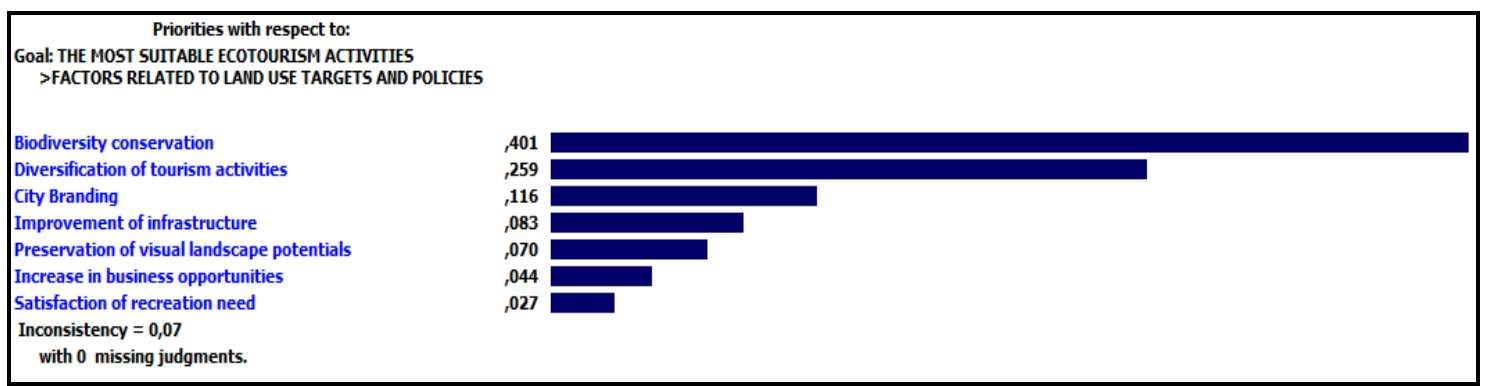

Figure 8. The weight ratios of the sub-factors of the main factor related to land use targets and policies

As a result of the binary comparison of alternatives with the factors related to land use targets and policies, botanical tourism received the highest weight ratio $(0.330)$ (Fig. 9).

\begin{tabular}{|c|c|c|}
\hline 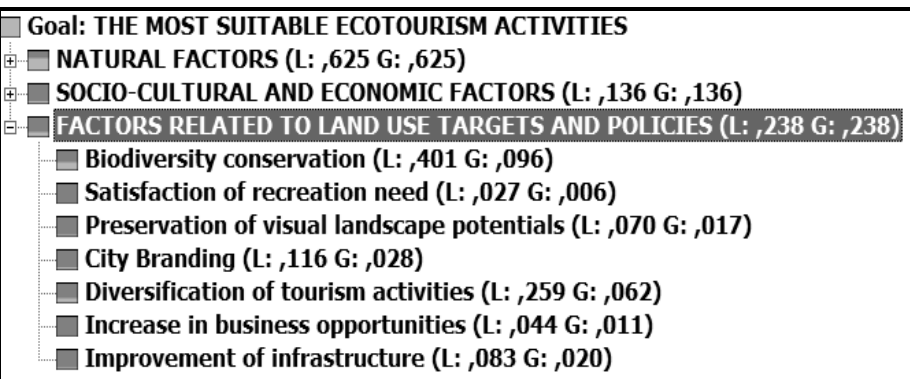 & \begin{tabular}{|l|} 
Botanical tourism \\
Trekking \\
Bird/butterfly watching \\
Photo safari \\
Bicycle safari \\
\end{tabular} & $\begin{array}{l}.330 \\
.222 \\
.152 \\
.179 \\
.118\end{array}$ \\
\hline
\end{tabular}

Figure 9. The weight ratios of the ecotourism activities based on the factors related to land use targets and policies

When the binary comparison was performed among the alternatives and the subfactors, such as biodiversity conservation, satisfaction of recreational needs, city branding and increase in business opportunities, botanical tourism obtained the highest weight ratio. In the case of the binary comparison among the alternatives and the subfactors, such as preservation of visual landscape potentials and diversification of tourism activities, trekking resulted in the highest weight ratio. The bicycle safari, however, received the highest weight ratio as a result of the binary comparison of alternatives with the sub-factor of improvement of infrastructure.

The sum of the weight ratios for all of the criteria was ' 1 '. Hence, the comparison was consistent since the resulting rate was $\mathrm{CR}<0.1$.

The sensitivity analysis performed on the main factors is presented in Figure 10. While the natural factors had a $62.5 \%$ significance level, botanical tourism was in the top position with a significance level of $31.3 \%$.

When the significance levels of socio-cultural and economic factors were increased from $13.6 \%$ to $65.2 \%$, the order of the alternatives did not change. Additionally, trekking still remained in the leading position (Fig. 11). 


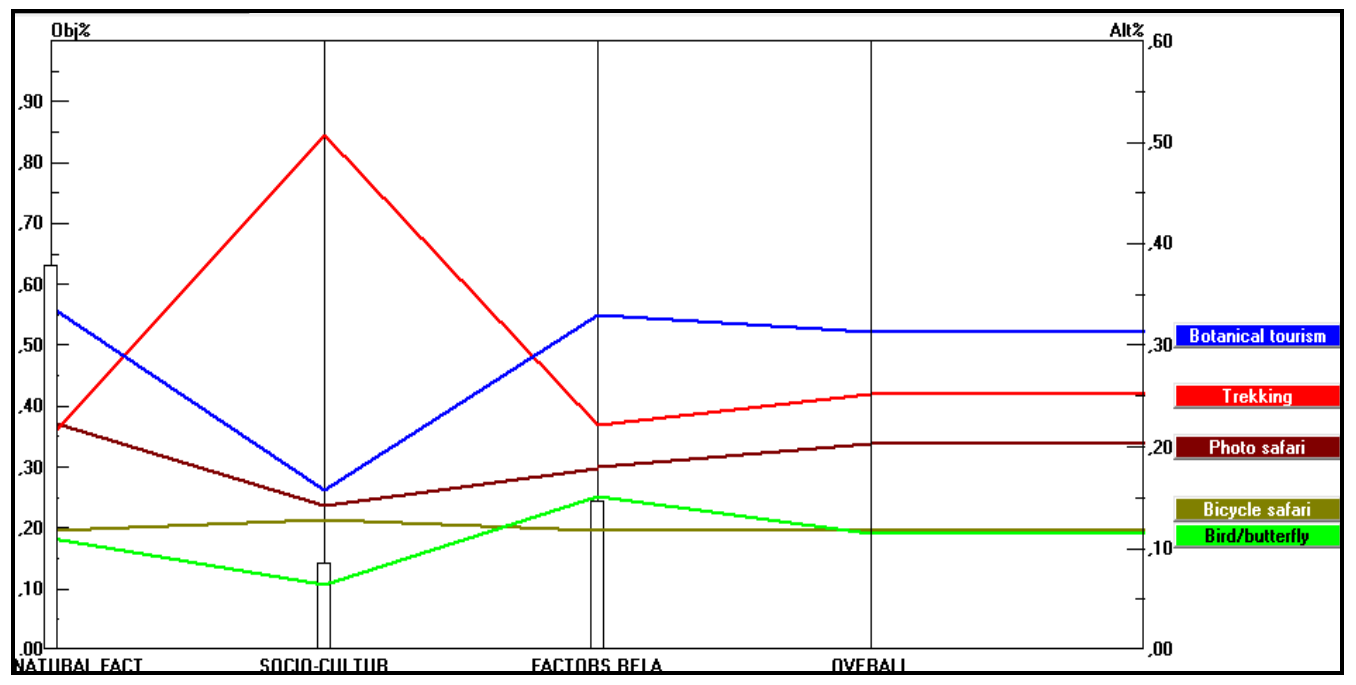

Figure 10. The sensitivity analysis of the main factors

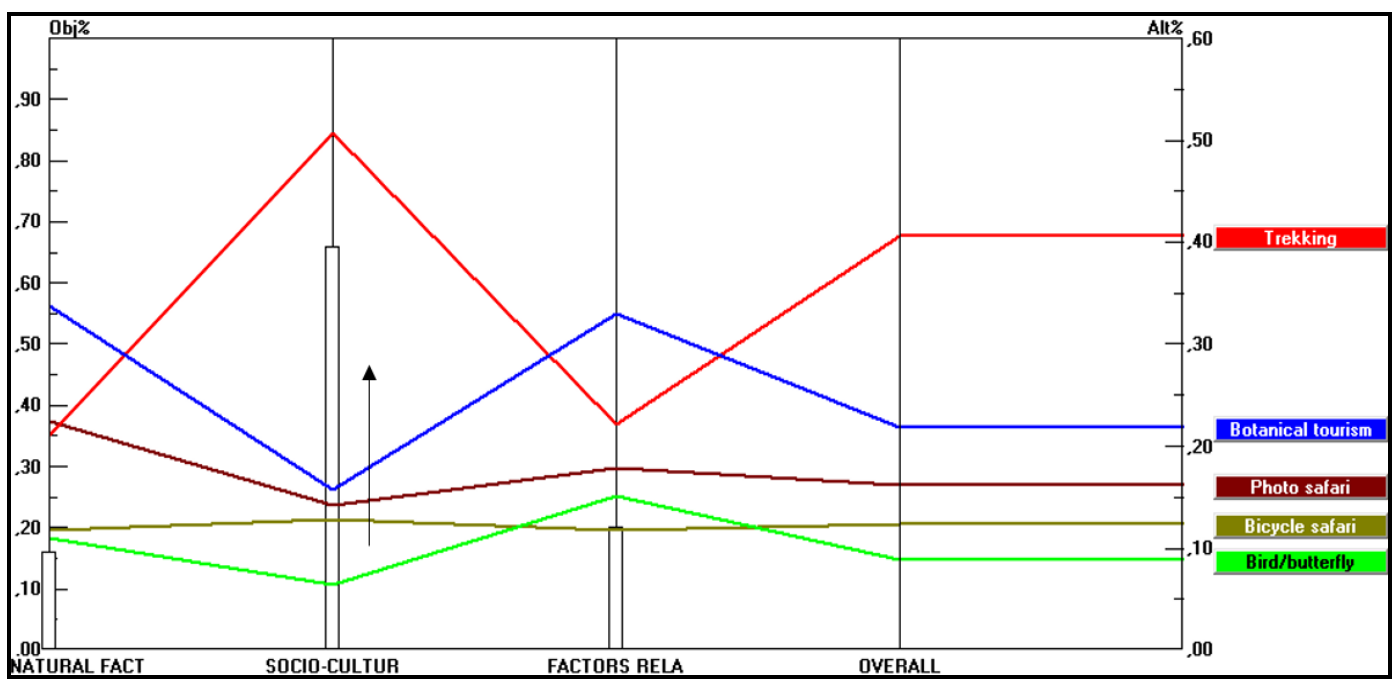

Figure 11. Significance level of socio-cultural and economic factors

Botanical tourism was also ranked the highest when the significance level of factors related to land use targets and policies was increased from $23.8 \%$ to $61.3 \%$ (Fig. 12). Hence, botanical tourism had a preferential significance level for BNP.

\section{SWOT analysis}

Field analyses and observations were made via visiting the field in different seasons. The current situation was determined by photo shoots. In addition, literature review was performed. In this context, the following studies and reports were analyzed; the 1st Revision of Development Plan and Report for the BNP prepared by the Bartın Provincial Directorate of Environment and Forest (Anonymous, 2006); the 'Strategic Goals and Provincial Development Plan' prepared by the Bartın Provincial Directorate of Planning and Coordination (Anonymous, 2008); the 'Bartın Province Tourism Action Plan' for 2012-2016 period prepared by the Bartın Provincial Directorate of Culture 
and Tourism (Anonymous, 2011); the 'Strategic Plan' for 2015-2019 period prepared by the Bartın Municipality (Anonymous, 2014); the 'Regional Plan' for 2010-2013 period prepared by the Western Black Sea Development Agency (Anonymous, 2009); and the article themed on the importance of open green areas in branding of Bartin Province (Çelik, 2017; Table 4). With this analysis, the strengths and weaknesses and opportunities and threats of BNP were determined. The study also determined how strengths and opportunities might be assessed and how weaknesses could be converted into strengths as well as what could be undertaken to remove the threats.

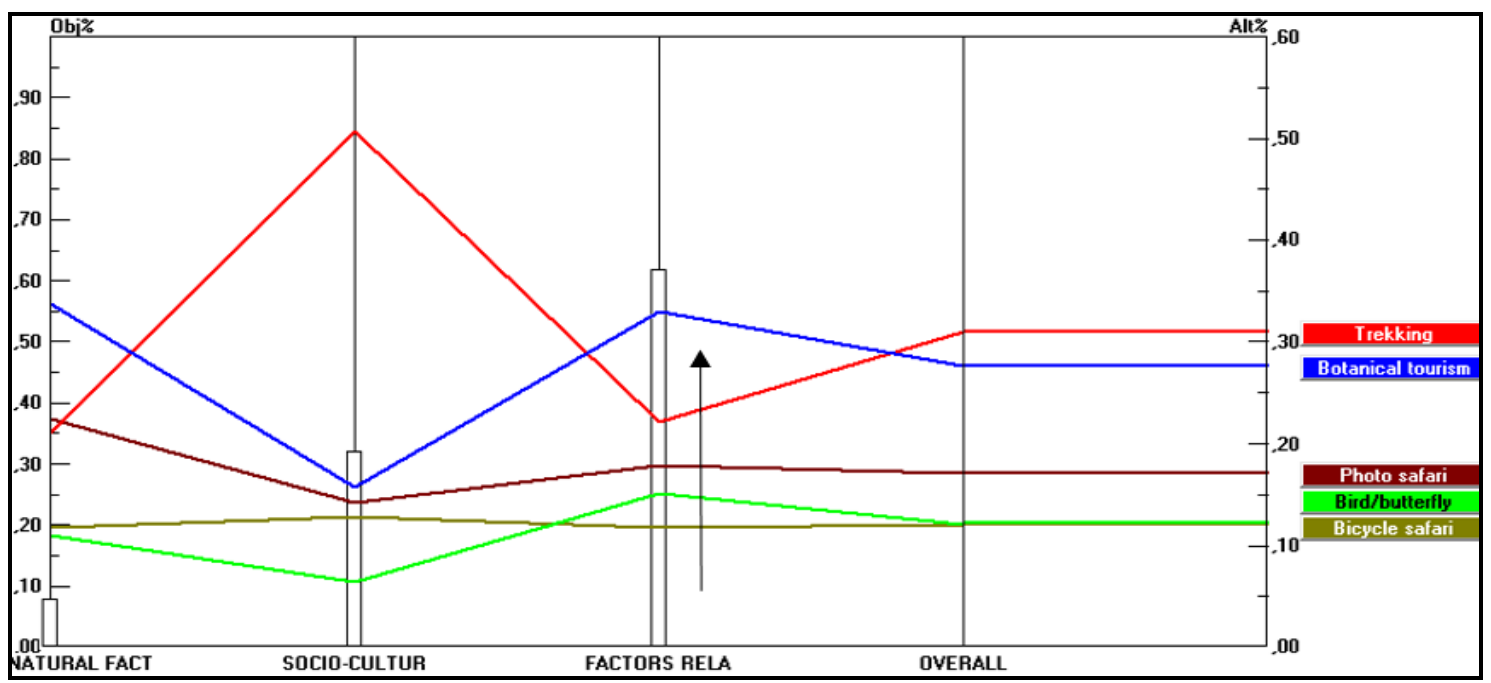

Figure 12. Significance level of factors related to land use targets and policies

As a result of the field analysis, the following issues were determined the strengths of BNP: absence of any residential areas and no deterioration of natural structures due to less frequent use, preparation of an in-progress development plan for the Park, presence of potential recreational activities, the existence of a safe environment, close proximity to important routes such as the Bartın-Karabuk Highway, and the famous destinations such as Amasra, Inkumu, Yedigoller, which have favourable climatic conditions and rich floral as well as faunal diversity, and finally, the absence of a property problem. As a result of the scientific research project (No.2016-FEN-A-001-author included) conducted in BNP, researchers determined that the Park contained a total of 50 families, 115 genera and 130 taxa. These aspects might be important forces for implementing ecotourism activities and for contributing positively to city branding as well as local and regional economic development. Again as a result of the surveys and observations, the positive reaction of the local community to development of the tourism sector, enthusiasm for environmental protection by both the local community and tourists, lack of agriculture and livestock activities, and tourist attraction potential of Bartin Province were considered opportunities in BNP. However, insufficient urban equipment and walking/running road information signage, lack of timely landscape maintenance and repair work, and insufficient promotional activity for BNP were considered weaknesses in the area. The absence of an application-oriented landscape project in this field of study, the lack of adequate investment activity in the tourism sector, and the increasing use of ecotourism activities that caused complications for biodiversity conservation were also listed as threats. 
Table 4. The SWOT analysis related to ecotourism

\begin{tabular}{l|l} 
- Suitable climate conditions for ecotourism activities \\
- \\
- Exhstence of an in-progress Development Plan for BNP \\
- Natural Park status
\end{tabular}

\section{Discussion}

Various studies have been conducted both in national and international literature to identify the natural and cultural potentials of national parks, natural conservation areas, and natural parks and to determine the most suitable recreational or ecotourism activities for these potentials. Similar or different aspects of this research with the other conducted studies were summarized below. For example, in a study based on the socio- 
economic and cultural structure of a local community in Ol Donyo Sapuk National Park in Kenya, the research noted that ecotourism would contribute to economic development at the local and regional scale (Owino et al., 2012). This result was also supported by Yunus et al. (2013). In a survey study conducted for a Malaysian National Park, researchers emphasized that the implementation of ecotourism would be appropriate for increasing the income level of a local community and for achieving land use conservation. Similarly, the conservative use of natural resources, maintenance of sustainability, and engaging in ecotourism activities to accelerate local development were also predicted for BNP. This study also determined that ecotourism activities would be primary contributors to the socio-economic structure of Bartin's local residents.

When studying the Iron Gates Natural Park in Romania, Boengiu (2012) initially examined the available resources and infrastructure in order to determine the development potential for tourism. As a result, the study stated that attractive natural resources and natural monuments had potential values for tourism. In addition, Öztürk (2005) investigated the natural and cultural landscape potential of Kastamonu-Bartin Kure Mountains National Park on the basis of recreation and ecotourism concepts and determined the most suitable activities for ecotourism. These included activities such as wildlife viewing, trekking, photography, etc. Using SWOT analysis, Orhan and Karahan (2010) identified Uzundere's natural and cultural landscape potentials and determined the relevant ecotourism activities. In this context, religious tourism, trips to Tortum Waterfall and Ruins, picnicking, and festivals were listed as promising tourism activities. Similar to these studies, the current potentials of BNP were determined using SWOT analysis. However, the proposed ecotourism activities for BNP were varied. BNP had the potential for activities such as trekking, botanical tourism, photo safaris, bicycle safaris, etc.

In a study conducted by Nahuelhual et al. (2013) on a local level in southern Chile, the researchers noted that the unprecedented natural beauty had recreational potential. Additionally, Aminzadeh and Ghorashi (2007) investigated the relationship between recreational activities and aesthetic and ecological potentials in their research, which was conducted in Siangtan Forest Park in Iran. As a result, they indicated that recreational activities attracted attention in areas of natural beauty instead of in designed spaces. Similarly, this research concluded that BNP also had rich flora. As a result of the floristic studies conducted in BNP, a total of 130 taxa were identified. The park contains recreational potential due to its natural landscape values. With organized events, tourists and local residents will receive benefits from these recreational and ecotourism activities.

Within the context of landscape planning/restoration, alternative land uses following mining activities were determined by Akpınar (1995) using the AHP method. These alternatives were also prioritized. The priority order of ecotourism activities in the Yusufeli District of Artvin Province was also determined using the AHP method from Y1lmaz and Surat (2015). According to the AHP analysis results, a nature exploration walk was identified as the ecotourism activity with the highest priority value. Similarly, BNP questionnaire data obtained from the experts were utilized in the AHP method, and the ecotourism activities, which could be implemented in BNP, were determined. The priority order of the ecotourism activities was determined; thus, botanical tourism was the top ranked activity. Other important activities identified were trekking, photo safaris, bicycle safaris, and bird/butterfly watching. 
To select the most suitable ecotourism activity in the Oltu and Olur Districts in Erzurum Province, a questionnaire was conducted using the AHP Method. The study emphasized that the ecotourism activities would contribute to promotion of the region (Akpınar Külekçi and Bulut, 2012). This result also aligns with the conclusion that ecotourism contributes to the promotion and branding of Bartın Province.

In a study conducted by Jalani (2012) in the Puerto Princesa Subterranean River National Park, the research stated that the local communities would receive new employment opportunities and their economic conditions would prosper due to ecotourism activities. In addition, the study concluded that city development would increase through ecotourism activities. These findings paralleled the results of the research performed in BNP. This study also concluded that the ecotourism activities in BNP would generate new employment opportunities for the local community and increase residents' economic incomes as well as the quality of urban infrastructure.

The existing natural and cultural values of the Karapinar District in Konya Province were determined using SWOT analysis. As a result, planning, management and monitoring requirements were emphasized in order to ensure the long-term sustainability of ecotourism (Önder and Polat, 2004). Similarly, the SWOT analysis technique was also used to determine the existing natural and cultural resources of Oltu District in Erzurum Province for the ecotourism potential. The research stated that development of ecotourism policies at regional and national scales was required to avoid harming the natural biota (Akpınar Külekçi and Bulut, 2013). The SWOT analysis performed for BNP also presented similar results. Ecotourism may be used as a tool for sustainable economic development at local, regional and national levels. In the tourism industry, attention should be given to planning, implementation, supervision and monitoring as well as to compliance with necessary laws and regulations.

Güngör and Polat (2017) stated that the local community in Konya was intensively using the urban parks for picnicking. They indicated that the visitor capacity of these parks could be at risk under such high pressure, and environmental pollution might increase to the degree that other visitors might feel uncomfortable. Therefore, the authors emphasized that allowing picnics and recreational activities, etc. in the forest area near the city might reduce this overuse pressure. Similar to that result, BNP has the characteristic of being a potential area for use as an alternative to publicly open green spaces in the city centre. By engaging in recreational events or ecotourism activities in $\mathrm{BNP}$, both local communities and tourists will contribute to reducing pressure on publicly open green spaces in the city centre. There are one hundred and four parks in Bartın city. These parks are different sizes, and including playground areas, sporting areas, hiking trail, etc. These urban open green areas have been extensively used in Bartın (Anonymous, 2014).

\section{Conclusions}

In conclusion; with the aim of determining the existing landscape characteristics of the BNP, literature reviews, field analyses and observations were performed. Literature reviews and data obtained for Bartın city were analyzed for the BNP. In this context, data were obtained regarding geographical location, transportation status, topographical and geological structures, climatic characteristics, flora and fauna characteristics, historical development, technical and social infrastructure, tourism and recreation relations. 
Questionnaire were also conducted to an expert group in order to determine the most suitable ecotourism activities in the identified landscape potentials. The surveys were analyzed using the AHP method. Experts recommended ecotourism activities in the following order such as botanical tourism, trekking, photo safari, bike safari, bird/butterfly watching in line with the current potentials of the BNP. Ecotourism may be used as a tool for conservation, and sustainable use of landscape values for the BNP.

The ecotourism activities have the power to contribute to economy and local tourism sector. Thus, it will be possible to diversify tourism activities and spread them throughout the year. Ecotourism activities also have a strong effect on the economy and contribute to positively activating the local tourism sector. Thus, diversification of tourism activities and extending the activities throughout the whole year is possible.

In this context, the following recommendations were developed for ecotourismoriented use of BNP:

- Initially, the visitor capacity of the park should be identified,

- Structural and botanical landscape design projects should be prepared to include disadvantaged groups,

- These projects should be conducted by a multi-disciplinary team,

- After the implementation of a project, landscape maintenance and repair work should be performed by a certain level of experts,

- Training activities should be planned to elevate the environmental protection awareness level,

- Tourism infrastructure should be developed in Bartın city centre,

- Promotional activities for Bartın and BNP should be increased.

In this process, it is very important to compel stakeholders to work together such as those from the public and private sectors, universities and NGOs (Non-Governmental Organizations) without any conflicting authorities. Planning, implementation, supervision controls should also be implemented, and compliance with laws and regulations should be considered.

Acknowledgements. This article relied on scientific research project No. 2016-FEN-A-001, entitled 'Assessment of Balamba Natural Park Landscape Potential in terms of Ecotourism'. The floristic research in the project was completed by Assoc. Prof. Zafer Kaya and Asst. Prof. Cevdet Gumus. I thank them for their contributions and participation in the project.

\section{REFERENCES}

[1] Açıksöz, S., Cetinkaya Ciftcioglu, G., Uzun, O., Erduran Nemutlu, F., Ilke, E. F. (2016): Linkages among ecotourism, landscape and natural resource management, and livelihood diversification in the region of Suğla Lake, Turkey. - International Journal of Sustainable Development \& World Ecology 23: 15-27.

[2] Akpınar Külekçi, E., Bulut, Y. (2012): Determination of the most convenient ecotourism activity in the Oltu and Olur Districts of Erzurum Province by using analytic hierarchy process. - Atatürk University Journal of the Agricultural Faculty 43: 175-189.

[3] Akpınar Külekçi, E., Bulut, Y. (2013): Oltu District of Erzurum Province to determine the potential ecotourism for SWOT analysis. - Artvin Coruh University Journal of Forestry Faculty 14: 1-12. 
[4] Akpınar, N. (1995): A Research on Evaluation of Post Mining Land Use Alternatives Using Fuzzy Set Technique. - Ankara University Faculty of Agriculture Publications: 1430, Scientific Research and Studies: 793, Ankara.

[5] Akten, M., Yılmaz, O., Gül, A. (2009): Determınatıon of recreatıonal land use factors for land use plannıng: case of isparta plaın. - Süleyman Demirel University Journal of Forestry Faculty 2: 119-133.

[6] Aminzadeh, B., Ghorashi, S. (2007): Scenic landscape quality and recreational activities in natural forest parks, Iran. - International Journal of Environmental Research 1: 5-13.

[7] Anonymous (2006): Balamba Mesire Yeri 1. Revizyon Gelisme Planı ve Plan Raporu (in Turkish). - T. C. Çevre ve Orman Bakanlığı Bartın İl Çevre ve Orman Müdürlüğü, Bartın.

[8] Anonymous (2008): Bartın 2023, Stratejik Amaçlar ve İl Gelişme Planı (in Turkish). - İl Planlama ve Koordinasyon Müdürlüğ̈̈, Bartın.

[9] Anonymous (2009): Batı Karadeniz Bölgesi (Zonguldak-Karabük-Bartın) Bölge Planı 2010-2013 (in Turkish). - Batı Karadeniz Kalkınma Ajansı (Western Black Sea Development Agency), Zonguldak.

[10] Anonymous (2011): Bartın İli Turizm Eylem Planı 2012-2016 (in Turkish). - Bartın Valiliği İl Kültür ve Turizm Müdürlüğü, Bartın.

[11] Anonymous (2014): Bartın Belediyesi 2015-2019 Dönemi Stratejik Planı (in Turkish). Bartın.

[12] Balamba Natural Park (BNP) (2017): http://bolge10.ormansu.gov.tr/10bolge/AnaSayfa/Korunan_Alanlarimiz/tabiatparki/balam batabiatparki.aspx?sflang=tr). - Accessed on 23 February 2017.

[13] Boengiu, V. (2012): Evaluation of tourism resources in the Iron Gates Natural Park in order to identify the potential of tourism development. - Analele Universităniii din Oradea-Seria Geografie 2: 234-240.

[14] Çelik, D. (2017): Researches on Science and Art in 21th Century Turkey. - In: Arapgirlioğlu, H., Elliott, R. L., Turgeon, E., Atik, A. (eds.) Significance of Natural Parks in Ecotourism and the Perception of the Local Residents' Preservation and Ecotourism: A Case Study of Balamba Natural Park in Bartın (pp. 717-726). Gece Kitaplığı Publishing House, Ankara.

[15] Ceylan, S. (2004): Yazılı Kanyon (Sütçüler, Isparta) Nature Park's priority and use in terms of tourism. - Süleyman Demirel University Journal of Burdur Education Faculty 5: 59-82.

[16] Cheia, G. (2013): Ecotourism: definition and concepts. - Revista de Turism 15: 56-60.

[17] Chen, Y. L., Perng, Y. H., Lien, H. C. (2014): Utility-based multicriteria model for evaluating real estate development projects. - Journal of Environmental Protection and Ecology 15: 1328-1336.

[18] Daşdemir, İ., Güngör, E. (2010): Determınıng of functıonal prioritıes of forest resources by multicriteria and participatory approach: Case of Ulus State Forest Enterprise. Journal of Bartın Foresty Faculty 12: 11-25.

[19] Ecotourism and Sustainable Tourism Association (ESTA) (2016): http://www.ekoturizmdernegi.org/ekotur.asp. - Accessed on 7 December 2016.

[20] Ecotourism Sector Report (ESR) (2012): Western Mediterranean Development Agency. https://www.baka.org.tr/uploads/1349952547EKOTURiZM-SEKTOR-RAPORU11EYLUL.pdf. Accessed on 5 December 2016.

[21] Eighth Five-Year Development Plan (EFYDP) (Sekizinci Beş Yillik Kalkinma Planı-in Turkish) (2017): http://www.bilgitoplumu.gov.tr/wpcontent/uploads/2015/01/Sekizinci_Kalkinma_Plani.pdf. - Accessed on 1 April 2017

[22] Erdoğan, N. (2003): Çevre ve (Eko)turizm (in Turkish). - ERK Publisher, Ankara.

[23] Establishment Purpose and Duties (EPD) (2017): Ministry of Culture and Tourism. https://www.kultur.gov.tr/TR,96130/kurulus-amaci-ve-gorevleri.html. - Accessed on 5 February 2017. 
[24] Fennell, D. (2001): A content analysis of ecotourism definitions. - Current Issues in Tourism 4: 403-421.

[25] Ghinolfi, D., El Baz, H. G., Borgonovi, E., Radwan., Laurence, O., Sayed, H. A., Simone, P. D., Abdelwadoud, M., Stefani, A., Botros, S. S., Filipponi, F. (2014): A model for Southern Mediterranean research institute self-assessment: a SWOT analysis-based approach to promote capacity building at Theodor Bilharz Research Institute in Cairo (Egypt). - Arab Journal of Gastroenterology 15: 92-97.

[26] Ghorbani, A., Raufirad, V., Rafiaani, P., Azadi, H. (2015): Ecotourism sustainable development strategies using SWOT and QSPM model: A case study of Kaji Namakzar Wetland, South Khorasan Province, Iran. - Tourism Management Perspectives 16: 290297.

[27] Gössling, S. (1999): Ecotourism: A means to safeguard biodiversity and ecosystem functions? - Ecological Economics 29: 303-320.

[28] Gumusay, M. U., Bakirman, T., Koseoglu, G. (2016): An assessment of site suitability for marina construction in Istanbul, Turkey, using GIS and AHP multicriteria decision analysis. - Environmental Monitoring and Assessment 188: 677.

[29] Güngör, S., Polat, A. T. (2017): The evaluation of the urban parks in Konya province in terms of quality, sufficiency, maintenance, and growth rate. - Environmental Monitoring and Assessment 189: 172.

[30] Gürlek, T. B. (2002): SWOT Analizi (in Turkish). - TÜBİTAK, Gebze, İstanbul.

[31] Hussin, R., Cooke, F. M., Kunjuraman, V. (2015): Community-based ecotourism (cbet) activities in abai village, lower kinabatangan area of sabah, east malaysia. - The International Conference on Natural Resources, Tourism and Services Management, 1517 April 2015, Sabah, Malaysia, pp. 169-175.

[32] İmren, E., Karayllmazlar, S., Kurt, R., Çabuk, Y. (2017): Use of AHS method in investment decision making: Example of Bartin Province. - Journal of Bartin Faculty of Forestry 19: 107-114.

[33] Jaafar, M., Maideen, S. A. (2012): Ecotourism-related products and activities, and the economic sustainability of small and medium island chalets. - Tourism Management 33: 683-691.

[34] Jalani, J, O. (2012): Local people's perception on the impacts and importance of ecotourism in Sabang, Palawan, Philippines. - Procedia - Social and Behavioral Sciences 57: 247-254.

[35] Kuvan, Y., Akan, P. (2005): Residents' attitudes toward general and forest-related impacts of tourism: The case of Belek, Antalya. - Tourism Management 26: 691-706.

[36] Lin, L. W., Chen, C. H., Chang, H. C., Chen, T. C. (2008): Applying the grey assessment to the evaluation system of ecological green space on greening projects in Taiwan. Environmental Monitoring and Assessment 136: 129-46.

[37] Lopez, R., Monteros, E. D. L. (2002): Evaluating ecotourism in natural protected areas of La Paz Bay, Baja California Sur, Mexico: ecotourism or nature-based tourism? Biodiversity and Conservation 11: 1539-1550.

[38] Medjoudj, R., Laifa, A., Aissani, D. (2012): Decision making on power customer satisfaction and enterprise profitability analysis using the Analytic Hierarchy Process. International Journal of Production Research 50: 4793-4805.

[39] Nahuelhual, L., Carmona, A., Lozada, P., Jaramillo, A., Aguayo, M. (2013): Mapping recreation and ecotourism as a cultural ecosystem service: An application at the local level in Southern Chile. - Applied Geography 40: 71-82.

[40] National Parks Law (NPL) http://www.mevzuat.gov.tr/MevzuatMetin/1.5.2873.pdf. - Accessed on 20 March 2016.

[41] Njoh, A. J. (2017): The SWOT model's utility in evaluating energy technology: Illustrative application of a modified version to assess the sawdust cookstove's sustainability in Sub-Saharan Africa. - Renewable and Sustainable Energy Reviews 69: 313-323. 
[42] Nyaupane, G. P., Thapa, B. (2004): Evalation of ecotourism: a comparative assessment in the Annapurna Conservation Area Project, Nepal. - Journal of Ecotourism 3: 20-45.

[43] Önder, S., Polat, A. T. (2004): Visual quality assessment and swot analysis ecotourism aspect for Karapinar country of Konya. - Selçuk University Journal of Agricultural Faculty 18: 80-86.

[44] Orhan, T., Karahan, F. (2010): Evaluation of ecotourism potential of Uzundere District and its environs. - Artvin Coruh University Journal of Forestry Faculty 11: 27-42.

[45] Owino, O., Jillo, A. H., Kenana, M. L. (2012): Socio-economics and wildlife conservation of a peri-urban national park in central Kenya. - Journal for Nature Conservation 20: 384-392.

[46] Öztürk, S. (2005): Examination of recreational source values in Kastamonu-Bartın Kure Mountains National Park. - Journal of Faculty of Forestry, Süleyman Demirel University 2: $138-148$.

[47] Protected Areas (PA) (2018): http://www.tabiat.gov.tr/tr/searchplaces. - Accessed on 20 February 2018

[48] Saaty, T. L. (1977): A scaling method for priorities in hierarchical structures. - Journal of Mathematical Psychology 15: 234-281.

[49] Saaty, T. L. (1994): How to make a decision: The analytic hierarchy process. - Interfaces 24: $19-43$

[50] Saaty, T. L., Vargas, L. G. (2006): Decision Making With the Analytic Network Process Economic, Political, Social and Technological Applications with Benefits, Opportunities, Costs and Risks. - Springer Science Business Media, New York.

[51] Scholl, A. (2005): Solving multiattribute design problems with Analytic Hierarchy Process and Conjoint Analysis: An empirical comparison. - European Journal of Operational Research 164: 760-777.

[52] Scolozzi, R., Schirpke, U., Morri, E., D’Amato, D., Santolini, R. (2014): Ecosystem services-based SWOT analysis of protected areas for conservation strategies. - Journal of Environmental Management 146: 543-551.

[53] Şener, Ş., Sener, E., Karagüzel, R. (2011): Solid waste disposal site selection with GIS and AHP methodology: a case study in Senirkent-Uluborlu (Isparta) Basin, Turkey. Environmental Monitoring and Assessment 173: 533-54.

[54] The International Ecotourism Society (TIES) (2017): http://www.ecotourism.org/what-isecotourism. - Accessed on 27 July 2017.

[55] Timor, M. (2011): Analitik Hiyerarşi Prosesi (in Turkish). - Turkmen Bookstore, İstanbul.

[56] Toskay, T. (1989): Tourism, General Approach to Tourism Event. - Istanbul University Faculty of Economics, İstanbul.

[57] Turkey's Tourism Strategy-2023 (TTS2023), Ministry of Culture and Tourism. www.resmigazete.gov.tr/eskiler/2007/03/20070302-17-1.doc. - Accessed on 3 January 2017.

[58] Verdugo, C., Vázquez, M. V., García, M. Á. O., Agüera, F. O. (2016): The relevance of psychological factors in the ecotourist experience satisfaction through ecotourist site perceived value. - Journal of Cleaner Production 124: 226-235.

[59] Wishitemia, E. L., Momanyi, S. O., Ombati, B. G., Okello, M. M. (2015): The link between poverty, environment and ecotourism development in areas adjacent to Maasai Mara and Amboseli protected areas, Kenya. - Tourism Management Perspectives 16: 306-317.

[60] Yilmaz, H., Surat, H. (2015): Determination of the most convenient ecotourism activity by using analytic hierarchy process. - Turkish Journal of Forestry 16: 164-176.

[61] Yunus, R. M., Karim, S. A., Samadi, Z. (2013): Gateway to sustainable national park. Procedia-Social and Behavioral Sciences 85: 296-307. 


\section{APPENDIX}

\section{Questionnaire}

\section{Determination of the priority with the analytic hierarchy process}

This questionnaire aimed to determine the most suitable ecotourism activities in the existing potentials Balamba Natural Park (BNP).

Table A1. The significance levels and their definitions used in the binary comparison among criteria (Saaty and Vargas, 2006)

\begin{tabular}{|c|c|}
\hline Significance level & Definition \\
\hline 1 & Equal importance \\
\hline 3 & Moderate importance \\
\hline 5 & Strong importance \\
\hline 7 & Very strong importance \\
\hline 9 & Extreme importance \\
\hline $2,4,6,8$ & Intermediate levels \\
\hline
\end{tabular}

\section{The binary comparison matrix of the main factors}

Natural factors

\begin{tabular}{|c|c|c|c|c|c|c|c|c|c|c|c|c|c|c|c|c|}
\hline 9 & 8 & 7 & 6 & 5 & 4 & 3 & 2 & 1 & 2 & $\begin{array}{l}3 \\
4\end{array}$ & 5 & 6 & 7 & 8 & 9 & $\begin{array}{l}\text { Socio-cultural and } \\
\text { economic factors }\end{array}$ \\
\hline 9 & 8 & 7 & 6 & 5 & 4 & 3 & 2 & 1 & 2 & 34 & 5 & 6 & 7 & 8 & 9 & $\begin{array}{l}\text { Factors related to land use } \\
\text { targets and policies }\end{array}$ \\
\hline
\end{tabular}

1- What is the relative significance of the following main factors in relation to the purpose of determining the most suitable ecotourism activity according to the existing potentials?

\begin{tabular}{|c|c|c|c|c|c|c|c|c|c|c|c|c|c|c|c|c|c|c|}
\hline $\begin{array}{c}\text { Socio-cultural and economic } \\
\text { factors }\end{array}$ & 9 & 8 & 7 & 6 & 5 & 4 & 3 & 2 & 1 & 2 & 3 & 4 & 5 & 6 & 7 & 8 & 9 & $\begin{array}{c}\text { Factors related to land use } \\
\text { targets and policies }\end{array}$ \\
\hline
\end{tabular}

2- What is the relative significance of the following the sub-factors related to natural factors in relation to the purpose of determining the most suitable ecotourism activity according to the existing potentials?

\begin{tabular}{|c|c|c|c|c|c|c|c|c|c|c|c|c|c|c|c|c|c|c|}
\hline \multirow{3}{*}{ Climate } & 9 & 8 & 7 & 6 & 5 & 4 & 3 & 2 & $\mathbf{1}$ & 2 & 3 & 4 & 5 & 6 & 7 & 8 & 9 & Flora/fauna \\
\cline { 2 - 12 } & 9 & 8 & 7 & 6 & 5 & 4 & 3 & 2 & $\mathbf{1}$ & 2 & 3 & 4 & 5 & 6 & 7 & 8 & 9 & Topography \\
\cline { 2 - 13 } & 9 & 8 & 7 & 6 & 5 & 4 & 3 & 2 & $\mathbf{1}$ & 2 & 3 & 4 & 5 & 6 & 7 & 8 & 9 & Geographical location \\
\hline
\end{tabular}

\begin{tabular}{|c|c|c|c|c|c|c|c|c|c|c|c|c|c|}
\hline \multirow{2}{*}{ Flora/fauna } & 98 & \begin{tabular}{l|l|}
8 & 7
\end{tabular} & 6 & $\begin{array}{l}54 \\
4\end{array}$ & 3 & 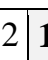 & \begin{tabular}{l|l|l} 
& 2 & 3 \\
\end{tabular} & \begin{tabular}{l|l}
3 & 4
\end{tabular} & 5 & 6 & $7 \mid \varepsilon$ & \begin{tabular}{l|l|}
8 & 9 \\
\end{tabular} & Topography \\
\hline & 98 & \begin{tabular}{l|l|l}
8 & 7
\end{tabular} & 6 & \begin{tabular}{l|l}
5 & 4
\end{tabular} & 3 & & 123 & \begin{tabular}{l|l}
3 & 4
\end{tabular} & 5 & & $7 \mid 8$ & \begin{tabular}{l|l|l}
8 & 9
\end{tabular} & Geographical location \\
\hline Topography & \begin{tabular}{|l|l|l|l}
9 & 8 \\
\end{tabular} & \begin{tabular}{l|l}
8 & 7
\end{tabular} & 6 & \begin{tabular}{l|l|l}
5 & 4
\end{tabular} & 3 & \begin{tabular}{|l|l}
2 & 1 \\
\end{tabular} & \begin{tabular}{l|l|l|l|}
1 & 2 & 3
\end{tabular} & \begin{tabular}{|l|l}
3 & 4 \\
\end{tabular} & \begin{tabular}{l|l}
4 & 5
\end{tabular} & 6 & \begin{tabular}{|l|l|l|l|l}
7 & $\varepsilon$ \\
\end{tabular} & \begin{tabular}{l|l}
8 & 9
\end{tabular} & Geographical location \\
\hline
\end{tabular}


3- What is the relative significance of the following the sub-factors related to socio-cultural and economic factors in relation to the purpose of determining the most suitable ecotourism activity according to the existing potentials?

\begin{tabular}{|c|c|c|c|c|c|c|c|c|c|c|c|c|c|c|c|c|c|}
\hline \multirow{3}{*}{ Transportation } & 9 & 8 & 7 & 6 & 5 & 4 & 3 & 2 & 1 & 2 & 3 & 4 & 56 & 5 & 8 & 9 & Economic status of visitors \\
\hline & 9 & 8 & 7 & 6 & 5 & 4 & 3 & 2 & 1 & 2 & 3 - & 4 & 56 & 57 & 8 & 9 & $\begin{array}{l}\text { Demographic structure of } \\
\text { visitors }\end{array}$ \\
\hline & 9 & 8 & 7 & 6 & 5 & 4 & 3 & 2 & 1 & 2 & 3 & 4 & 56 & 57 & 8 & 9 & $\begin{array}{l}\text { Existence of nearby } \\
\text { attraction centres }\end{array}$ \\
\hline
\end{tabular}

\begin{tabular}{|c|c|c|c|c|c|c|c|c|c|c|c|c|c|}
\hline Economis ctotus of vicitor & 98 & & 6 & & \begin{tabular}{l|l|l}
4
\end{tabular} & 2 & & 3 & 4 & 56 & 78 & 89 & $\begin{array}{l}\text { Demographic structure of } \\
\text { visitors }\end{array}$ \\
\hline 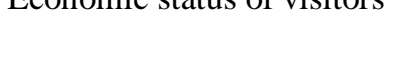 & 98 & & 6 & & & 2 & & & 4 & 56 & 7 & 9 & $\begin{array}{l}\text { Existence of nearby } \\
\text { attraction centres }\end{array}$ \\
\hline
\end{tabular}

\begin{tabular}{|c|c|c|c|c|c|c|c|c|c|c|c|c|c|c|c|c|c|c|}
\hline $\begin{array}{c}\text { Demographic structure of } \\
\text { visitors }\end{array}$ & 9 & 8 & 7 & 6 & 5 & 4 & 3 & 2 & 1 & 2 & 3 & 4 & 5 & 6 & 7 & 8 & 9 & $\begin{array}{c}\text { Existence of nearby } \\
\text { attraction centres }\end{array}$ \\
\hline
\end{tabular}

4- What is the relative significance of the following the sub-factors of land use targets and policies in relation to the purpose of determining the most suitable ecotourism activity according to the existing potentials?

\begin{tabular}{|c|c|c|c|c|c|c|c|c|c|c|c|c|c|c|c|}
\hline \multirow{6}{*}{ Biodiversity conservation } & 9 & & & 5 & 4 & 32 & 21 & 2 & 3 & 4 & 56 & 7 & & 9 & $\begin{array}{c}\text { Satisfaction of recreational } \\
\text { needs }\end{array}$ \\
\hline & 9 & & 76 & 5 & 4 & 32 & $2 \mid 1$ & 2 & 3 & 4 & 56 & 7 & & 9 & $\begin{array}{l}\text { Preservation of visual } \\
\text { landscape potentials }\end{array}$ \\
\hline & 9 & 8 & 76 & 5 & 4 & 3 & 21 & 2 & 3 & 4 & 56 & & 8 & 9 & City branding \\
\hline & 9 & & 76 & 5 & 4 & 3 & $2 \mid 1$ & 12 & 3 & 4 & 56 & 7 & 8 & 9 & $\begin{array}{c}\text { Diversification of tourism } \\
\text { activities }\end{array}$ \\
\hline & 9 & 8 & 76 & 5 & 4 & 3 & $2 \mid 1$ & 12 & 3 & 4 & 56 & 7 & 8 & 9 & $\begin{array}{l}\text { Increase in business } \\
\text { opportunities }\end{array}$ \\
\hline & 9 & 8 & 76 & 5 & 4 & 3 & 2 & 12 & 3 & 4 & 6 & & & 9 & $\begin{array}{l}\text { Improvement of } \\
\text { infrastructure }\end{array}$ \\
\hline
\end{tabular}

\begin{tabular}{|c|c|c|c|c|c|c|c|c|c|c|c|c|c|c|}
\hline \multirow{5}{*}{$\begin{array}{c}\text { Satisfaction of recreational } \\
\text { needs }\end{array}$} & \begin{tabular}{|l|l}
9 & 8
\end{tabular} & 7 & 6 & & 43 & 2 & $1 \mid 2$ & 23 & 4 & & \begin{tabular}{l|l}
6 & 7
\end{tabular} & & 9 & $\begin{array}{l}\text { Preservation of visual } \\
\text { landscape potentials }\end{array}$ \\
\hline & \begin{tabular}{l|l}
9 & 8
\end{tabular} & 7 & 6 & 5 & 43 & 2 & 1 & 23 & 4 & & $6 \quad 7$ & & 9 & City branding \\
\hline & \begin{tabular}{l|l}
9 & 8
\end{tabular} & 7 & 6 & 5 & 43 & 2 & 12 & 23 & 4 & & 67 & & 9 & $\begin{array}{c}\text { Diversification of tourism } \\
\text { activities }\end{array}$ \\
\hline & \begin{tabular}{l|l}
9 & 8
\end{tabular} & 7 & 6 & 5 & 43 & 2 & 12 & 23 & 4 & & $6 \quad 7$ & & 9 & $\begin{array}{l}\text { Increase in business } \\
\text { opportunities }\end{array}$ \\
\hline & \begin{tabular}{|l|l|l}
9 & 8
\end{tabular} & 7 & 6 & 5 & $\begin{array}{lll}4 & 3\end{array}$ & & 12 & 23 & & & $6 \quad 7$ & & 9 & $\begin{array}{c}\text { Improvement of } \\
\text { infrastructure }\end{array}$ \\
\hline
\end{tabular}

Preservation of visual landscape potentials

\begin{tabular}{|c|c|c|c|c|c|c|c|c|c|c|c|c|c|c|c|}
\hline 9 & 8 & 7 & 6 & 5 & 4 & 32 & 2 & 2 & 3 & 4 & 5 & 67 & 78 & 9 & City branding \\
\hline 9 & 8 & 7 & 6 & 5 & 43 & 32 & 2 & 2 & 3 & 4 & 5 & 67 & 78 & 9 & $\begin{array}{c}\text { Diversification of tourism } \\
\text { activities }\end{array}$ \\
\hline
\end{tabular}




\begin{tabular}{|c|c|c|c|c|c|c|c|c|c|c|c|c|c|c|c|c|c|c|}
\hline \multirow{2}{*}{\multicolumn{2}{|c|}{$x^{2}$}} & 9 & 8 & 7 & 6 & 5 & 4 & 3 & 2 & 12 & 2 & 34 & 45 & 6 & 7 & 8 & 9 & $\begin{array}{c}\text { Increase in business } \\
\text { opportunities }\end{array}$ \\
\hline & & 9 & 8 & 7 & 6 & 5 & 4 & 3 & 2 & 1 & 2 & 3 & 45 & 6 & 7 & 8 & 9 & $\begin{array}{l}\text { Improvement of } \\
\text { infrastructure }\end{array}$ \\
\hline
\end{tabular}

\begin{tabular}{|c|c|c|c|c|c|c|c|c|c|c|c|c|c|c|c|c|c|c|}
\hline & 9 & 8 & 7 & 6 & 5 & 4 & 3 & 2 & 1 & 2 & 3 & 4 & 5 & 6 & 7 & 8 & 9 & $\begin{array}{c}\text { Diversification of tourism } \\
\text { activities }\end{array}$ \\
\cline { 2 - 10 } City branding & 9 & 8 & 7 & 6 & 5 & 4 & 3 & 2 & $\mathbf{1}$ & 2 & 3 & 4 & 5 & 6 & 7 & 8 & 9 & $\begin{array}{c}\text { Increase in business } \\
\text { opportunities }\end{array}$ \\
\hline
\end{tabular}

\begin{tabular}{|c|c|c|c|c|c|c|c|c|c|c|c|c|c|c|c|c|c|c|}
\hline $\begin{array}{c}\text { Diversisfication of tourism } \\
\text { activities }\end{array}$ & 9 & 8 & 7 & 6 & 5 & 4 & 3 & 2 & $\mathbf{1}$ & 2 & 3 & 4 & 5 & 6 & 7 & 8 & 9 & $\begin{array}{c}\text { Increase in business } \\
\text { opportunities }\end{array}$ \\
\cline { 2 - 10 } & 9 & 8 & 7 & 6 & 5 & 4 & 3 & 2 & $\mathbf{1}$ & 2 & 3 & 4 & 5 & 6 & 7 & 8 & 9 & $\begin{array}{c}\text { Improvement of } \\
\text { infrastructure }\end{array}$ \\
\hline
\end{tabular}

\section{Increase in business} opportunities

$$
\begin{array}{|l|l|l|l|l|l|l|l|l|l|l|l|l|l|l|l|l|}
9 & 8 & 7 & 6 & 5 & 4 & 3 & 2 & \mathbf{1} & 2 & 3 & 4 & 5 & 6 & 7 & 8 & 9 \\
\hline
\end{array}
$$
infrastructure

\section{Relevant importance of ecotourism activities according to sub-criteria of natural factors criterion}

1- What is the relative importance of the following activities related to climate sub-factors in order to determine the most suitable ecotourism activity according to the existing potentials?

\begin{tabular}{|c|c|c|c|c|c|c|c|c|c|c|c|c|c|c|}
\hline \multirow{4}{*}{ Botanical tourism } & 98 & \begin{tabular}{l|l|l}
8 & 7
\end{tabular} & 6 & $5 \mid 4$ & 3 & 2 & & & 4 & 5 & 57 & & 9 & Trekking \\
\hline & 98 & $\begin{array}{lll}8 & 7\end{array}$ & 65 & 5 & 3 & 2 & & t & 4 & 5 & 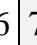 & & 9 & Bird/butterfly watching \\
\hline & \begin{tabular}{l|l}
9 & 8
\end{tabular} & \begin{tabular}{l|l}
8 & 7
\end{tabular} & 6 & $5 \mid 4$ & 3 & 2 & & & 4 & 5 & 677 & & 9 & Photo safari \\
\hline & \begin{tabular}{l|l}
9 & 8 \\
\end{tabular} & \begin{tabular}{l|l|l}
8 & 7
\end{tabular} & $6 \mid$ & $5 \mid 4$ & & 2 & 1 & 23 & 4 & & 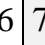 & & 9 & Bicycle safari \\
\hline
\end{tabular}

\begin{tabular}{|c|c|c|c|c|c|c|c|c|c|c|c|c|c|c|c|}
\hline \multirow{3}{*}{ Trekking } & 9 & 8 & 76 & 5 & 4 & 3 & 21 & 2 & 3 & 4 & 5 & 67 & & 9 & Bird/butterfly watching \\
\hline & 9 & 8 & 76 & 5 & 4 & 3 & $\begin{array}{lll}2 & 1 & \end{array}$ & 2 & 3 & 4 & 5 & 67 & & 9 & Photo safari \\
\hline & 9 & 8 & 76 & 5 & 4 & 3 & $2 \mid 1$ & 2 & 3 & 4 & 5 & 67 & & 9 & Bicycle safari \\
\hline
\end{tabular}

Bird/butterfly watching

\begin{tabular}{|c|c|c|c|c|c|c|c|c|c|c|c|c|c|}
\hline 9 & \begin{tabular}{l|l}
8 & 7
\end{tabular} & \begin{tabular}{l|l}
7 & 6
\end{tabular} & & $4 \sqrt[3]{3} \cdot 3$ & 2 & 1 & 2 & \begin{tabular}{|l|l}
3 & 4
\end{tabular} & \begin{tabular}{l|l}
4 & 5
\end{tabular} & 6 & $7 \mid 8$ & \begin{tabular}{l|l}
8 & 9
\end{tabular} & Photo safari \\
\hline 9 & \begin{tabular}{l|l}
8 & 7
\end{tabular} & 76 & 5 & 43 & 2 & 1 & 2 & \begin{tabular}{|l|l}
3 & 4
\end{tabular} & $4 \quad 5$ & 6 & 78 & \begin{tabular}{l|l}
8 & 9
\end{tabular} & Bicycle safar \\
\hline
\end{tabular}

Photo safari

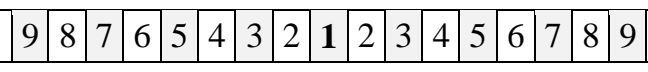

Bicycle safari

2- What is the relative importance of the following activities related to flora/fauna sub-factors in order to determine the most suitable ecotourism activity according to the existing potentials?

\begin{tabular}{|c|c|c|c|c|c|c|c|c|c|c|c|c|c|c|c|}
\hline \multirow{4}{*}{ Botanical tourism } & 9 & & & 55 & 54 & 3 & 2 & 1 & 23 & \begin{tabular}{l|l}
3 & 4
\end{tabular} & 5 & 6 & \begin{tabular}{|l|l|l} 
& $\varepsilon$ \\
\end{tabular} & \begin{tabular}{l|l}
8 & 9
\end{tabular} & Trekking \\
\hline & 9 & 87 & 7 & 55 & 54 & 3 & 2 & 1 & $2 \sqrt[3]{3}$ & 34 & 5 & 6 & \begin{tabular}{|l|l|l}
7 & 8 \\
\end{tabular} & \begin{tabular}{l|l}
8 & 9
\end{tabular} & Bird/butterfly watching \\
\hline & 9 & 877 & & 55 & 54 & 3 & 2 & 1 & $2 \mid 3$ & \begin{tabular}{l|l}
3 & 4
\end{tabular} & 5 & 6 & $7 \mid 8$ & $\begin{array}{ll}8 & 9\end{array}$ & Photo safari \\
\hline & 9 & 87 & 7 & 55 & 54 & 3 & 2 & 1 & 23 & $\begin{array}{ll}3 & 4 \\
\end{array}$ & 5 & 6 & \begin{tabular}{|l|l}
7 & 8
\end{tabular} & \begin{tabular}{l|l}
8 & 9
\end{tabular} & Bicycle safari \\
\hline
\end{tabular}




\begin{tabular}{|c|c|c|c|c|c|c|c|c|c|c|c|c|c|}
\hline \multirow{3}{*}{ Trekking } & \begin{tabular}{|l|l|l}
9 & $\varepsilon$ & $\varepsilon$
\end{tabular} & \begin{tabular}{l|l}
8 & 7
\end{tabular} & 65 & \begin{tabular}{l|l}
5 & 4
\end{tabular} & 3 & $2 \mid 1$ & $1 \mid 2$ & 3 & & & 7 & & Bird/butterfly watching \\
\hline & \begin{tabular}{|l|l|l|l}
9 & $\varepsilon$ & $r$
\end{tabular} & \begin{tabular}{l|l}
8 & 7
\end{tabular} & 65 & \begin{tabular}{l|l}
5 & 4
\end{tabular} & 3 & \begin{tabular}{l|l}
2 & 1
\end{tabular} & $1 \quad 2$ & 3 & 4 & & 7 & $8: 5$ & Photo safari \\
\hline & \begin{tabular}{|l|l|l|}
9 & $\varepsilon$ \\
\end{tabular} & \begin{tabular}{l|l}
8 & 7
\end{tabular} & 65 & \begin{tabular}{l|l}
5 & 4 \\
\end{tabular} & 3 & \begin{tabular}{l|l}
2 & 1
\end{tabular} & \begin{tabular}{l|l}
1 & 2
\end{tabular} & 3 & 4 & & 7 & 85 & Bicycle safari \\
\hline
\end{tabular}

Bird/butterfly watching

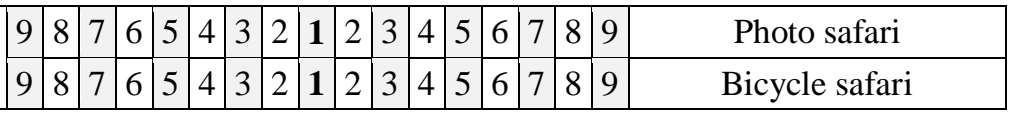

Photo safari

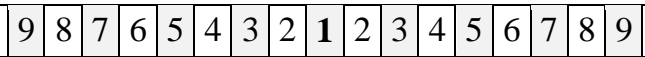

Bicycle safari

3- What is the relative importance of the following activities related to topography sub-factors in order to determine the most suitable ecotourism activity according to the existing potentials?

\begin{tabular}{|c|c|c|c|c|c|c|c|c|c|c|c|c|c|c|}
\hline \multirow{4}{*}{ Botanical tourism } & 9 & & 6 & $5 \mid 4$ & $4 \quad 3$ & 2 & $1 ?$ & 3 & 4 & 5 & 5 & & 9 & Trekking \\
\hline & 9 & \begin{tabular}{l|l}
8 & 7 \\
\end{tabular} & 6 & 54 & 43 & 2 & 1 & 3 & 4 & 5 & 6 & & 9 & Bird/butterfly watching \\
\hline & 9 & \begin{tabular}{l|l}
8 & 7
\end{tabular} & 6 & \begin{tabular}{l|l}
5 & 4 \\
\end{tabular} & $4 \quad 3$ & 2 & 1 & 3 & 4 & 5 & 6 & & 9 & Photo safari \\
\hline & 9 & \begin{tabular}{l|l}
8 & 7
\end{tabular} & 6 & & $4 \sqrt[3]{3}$ & 2 & 1 & & 4 & 5 & $\begin{array}{l}6 \\
67\end{array}$ & & 9 & Bicycle safari \\
\hline
\end{tabular}

\begin{tabular}{|c|c|c|c|c|c|c|c|c|c|c|}
\hline \multirow{3}{*}{ Trekking } & \begin{tabular}{|l|l|l}
9 & 8 \\
\end{tabular} & \begin{tabular}{l|l|l}
8 & 7 & 6 \\
\end{tabular} & & \begin{tabular}{|l|l|l}
4 & 3 \\
\end{tabular} & 2 & 1 & 23 & 4 & & Bird/butterfly watching \\
\hline & \begin{tabular}{|l|l}
9 & 8 \\
\end{tabular} & \begin{tabular}{l|l|l}
8 & 7 & 6
\end{tabular} & \begin{tabular}{l|l|}
6 & 5 \\
\end{tabular} & \begin{tabular}{|l|l|l}
4 & 3 \\
\end{tabular} & 2 & 1 & 2 & 4 & 5 & Photo safari \\
\hline & \begin{tabular}{|l|l}
9 & 8 \\
\end{tabular} & \begin{tabular}{l|l|l}
8 & 7 & 6
\end{tabular} & \begin{tabular}{l|l|}
6 & 5 \\
\end{tabular} & \begin{tabular}{|l|l|l|l|}
4 & 3
\end{tabular} & \begin{tabular}{|l|l|}
3 & 2 \\
\end{tabular} & 1 & & 4 & & Bicycle safari \\
\hline
\end{tabular}

Bird/butterfly watching

\begin{tabular}{|c|c|c|c|c|c|c|c|c|c|c|c|c|c|}
\hline & \begin{tabular}{l|l}
8 & 7
\end{tabular} & & & & 2 & 1 & 2 & 4 & & 6 & & 9 & Photo safari \\
\hline 9 & 7 & 6 & 5 & 3 & 2 & 1 & 2 & & & 6 & & 9 & Bicycle safari \\
\hline
\end{tabular}

Photo safari

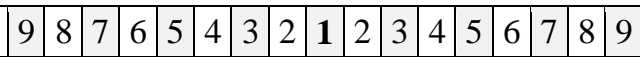

Bicycle safari

4- What is the relative importance of the following activities related to geographical location sub-factors in order to determine the most suitable ecotourism activity according to the existing potentials?

\begin{tabular}{|c|c|c|c|c|c|c|c|c|c|c|c|c|c|c|c|}
\hline \multirow{4}{*}{ Botanical tourism } & 9 & 8 & & 65 & 4 & 3 & 2 & 12 & 23 & 4 & 5 & 6 & 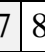 & 39 & Trekking \\
\hline & 9 & 8 & 7 & 65 & 4 & 3 & 2 & 12 & 3 & 4 & 5 & 67 & 78 & 39 & Bird/butterfly watching \\
\hline & 9 & 8 & 7 | & 65 & 4 & 3 & 2 & 12 & 23 & 4 & 5 & 6 & & 39 & Photo safari \\
\hline & 9 & 8 & \begin{tabular}{l|l}
7 & \\
\end{tabular} & $\begin{array}{ll}65 \\
\end{array}$ & 4 & 3 & 2 & 12 & 23 & 4 & 5 & \begin{tabular}{|l|l|}
6 & 7 \\
\end{tabular} & & 39 & Bicycle safari \\
\hline \multirow{3}{*}{ Trekking } & 9 & 8 & 7 & $\begin{array}{l}6 \\
6\end{array}$ & 4 & 3 & 2 & 12 & 3 & 4 & 5 & $6 \mid 7$ & 78 & 9 & Bird/butterfly watching \\
\hline & 9 & 8 & 7 & 65 & 4 & 3 & 2 & 12 & 3 & 4 & 5 & 6 7 7 & 78 & 9 & Photo safari \\
\hline & 9 & 8 & 76 & \begin{tabular}{c|c}
6 & 5
\end{tabular} & 4 & 3 & 2 & 12 & 3 & 4 & 5 & 6 6 7 & & 9 & Bicycle safari \\
\hline
\end{tabular}

Bird/butterfly watching

\begin{tabular}{|l|l|l|l|l|l|l|l|l|l|l|l|l|l|l|l|l|l|}
9 & 8 & 7 & 6 & 5 & 4 & 3 & 2 & $\mathbf{1}$ & 2 & 3 & 4 & 5 & 6 & 7 & 8 & 9 & Photo safari \\
\hline 9 & 8 & 7 & 6 & 5 & 4 & 3 & 2 & $\mathbf{1}$ & 2 & 3 & 4 & 5 & 6 & 7 & 8 & 9 & Bicycle safari \\
\hline
\end{tabular}

Photo safari

\begin{tabular}{l|l|l|l|l|l|l|l|l|l|l|l|l|l|l|l|l|}
9 & 8 & 7 & 6 & 5 & 4 & 3 & 2 & $\mathbf{1}$ & 2 & 3 & 4 & 5 & 6 & 7 & 8 & 9 \\
\hline
\end{tabular}

Bicycle safari 


\section{Relative importance of ecotourism activities according to sub-criteria of socio- cultural and economic criteria}

1- What is the relative importance of the following activities related to transportation subfactors in order to determine the most suitable ecotourism activity according to the existing potentials?

\begin{tabular}{|c|c|c|c|c|c|c|c|c|c|c|c|c|c|c|}
\hline \multirow{4}{*}{ Botanical tourism } & 9 & \begin{tabular}{l|l|l}
8 & 7 \\
\end{tabular} & \begin{tabular}{|c|c|c|c|} 
& 5 \\
\end{tabular} & \begin{tabular}{l|l|l}
5 & 4 \\
\end{tabular} & 3 & 2 & 12 & & 4 & & 2 & & 9 & Trekking \\
\hline & 9 & \begin{tabular}{l|l|l|}
8 & 7 & -1
\end{tabular} & \begin{tabular}{|l|l}
6 & 5
\end{tabular} & \begin{tabular}{c|c|c|c|}
5 & 4
\end{tabular} & 3 & 2 & $1 \mid 2$ & & 4 & & 7 & & 9 & Bird/butterfly watching \\
\hline & 9 & \begin{tabular}{l|l|l|}
8 & 7 & -10
\end{tabular} & \begin{tabular}{|l|l|l|l|l|}
6 & 5
\end{tabular} & \begin{tabular}{l|l|l}
5 & 4 & \multicolumn{1}{c}{$(x)$}
\end{tabular} & 3 & 2 & $1 \mid 2$ & 3 & 4 & & 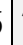 & & 9 & Photo safari \\
\hline & 9 & \begin{tabular}{l|l|l|}
8 & 7 & -10
\end{tabular} & \begin{tabular}{|l|l|l|l|l|}
6 & 5
\end{tabular} & 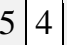 & 3 & 2 & $1 \mid 2$ & & 4 & & 5 & & 9 & Bicycle safari \\
\hline
\end{tabular}

\begin{tabular}{|c|c|c|c|c|c|c|c|c|c|c|c|c|c|}
\hline \multirow{3}{*}{ Trekking } & \begin{tabular}{|l|l}
9 & $\varepsilon$ \\
\end{tabular} & 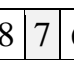 & \begin{tabular}{l|l}
6 & 5 \\
\end{tabular} & 4 & & 1 & 2 & & & & 7 & & Bird/butterfly watching \\
\hline & \begin{tabular}{|l|l|l|l}
9 & 8 & $c$
\end{tabular} & \begin{tabular}{|l|l|}
8 & 7 \\
\end{tabular} & \begin{tabular}{|l|l}
6 & 5 \\
\end{tabular} & 4 & 32 & & 22 & 3 & 4 & 6 & 7 & 8 & Photo safari \\
\hline & \begin{tabular}{|l|l}
9 & 8
\end{tabular} & \begin{tabular}{l|l|}
8 & 7 \\
\end{tabular} & \begin{tabular}{|l|l|}
6 & 5 \\
\end{tabular} & 5 & & & 2 & 3 & $4: 5$ & 56 & & 8 & Bicycle safari \\
\hline
\end{tabular}

Bird/butterfly watching

\begin{tabular}{|c|c|c|c|c|c|c|c|c|c|c|c|c|c|}
\hline 9 & $7 \mid 6$ & $6 \quad 5$ & \begin{tabular}{|l|l|}
5 & 4 \\
\end{tabular} & & 2 & $1 \mid 2$ & & 4. & 6 & & & 9 & Photo safari \\
\hline 9 & & 5 & \begin{tabular}{|l|l|}
5 & 4 \\
\end{tabular} & 3 & 2 & \begin{tabular}{l|l}
1 & 2
\end{tabular} & 3 & 4 & \begin{tabular}{l|l}
5 & 6
\end{tabular} & 7 & & 9 & Bicycle safari \\
\hline
\end{tabular}

Photo safari

\begin{tabular}{l|l|l|l|l|l|l|l|l|l|l|l|l|l|l|l|l|}
9 & 8 & 7 & 6 & 5 & 4 & 3 & 2 & $\mathbf{1}$ & 2 & 3 & 4 & 5 & 6 & 7 & 8 & 9
\end{tabular}

Bicycle safari

2- What is the relative importance of the following activities related to economic status of visitors sub-factors in order to determine the most suitable ecotourism activity according to the existing potentials?

\begin{tabular}{|c|c|c|c|c|c|c|c|c|c|c|c|c|c|}
\hline \multirow{4}{*}{ Botanical tourism } & 9 & \begin{tabular}{|l|l}
8 & 7
\end{tabular} & \begin{tabular}{l|l|l|}
7 & 6 \\
\end{tabular} & \begin{tabular}{c|c}
5 & 4
\end{tabular} & & 21 & 1 & 3 & & 6 & 7 & 89 & Trekking \\
\hline & 9 & 877 & \begin{tabular}{l|l|l|}
7 & 6 \\
\end{tabular} & \begin{tabular}{l|l}
5 & 4
\end{tabular} & 3 & \begin{tabular}{|l|llll}
2 & 1 & $l$ & $l$
\end{tabular} & 12 & 3 & & 6 & 7 & $8 \quad 9$ & Bird/butterfly watching \\
\hline & 9 & $877 \quad r$ & $7 \mid 6$ & \begin{tabular}{l|l}
5 & 4
\end{tabular} & 3 & \begin{tabular}{|l|lllll}
2 & 1 & & $l$
\end{tabular} & 12 & $3 \mid$ & & 6 & & $8 \quad 9$ & Photo safari \\
\hline & 9 & & \begin{tabular}{l|l|l|}
7 & 6 \\
\end{tabular} & \begin{tabular}{l|l}
5 & 4
\end{tabular} & & & $1 \mid 2$ & $3 \mid$ & & 6 & & 89 & Bicycle safari \\
\hline
\end{tabular}

\begin{tabular}{|c|c|c|c|c|c|c|c|c|c|c|c|c|c|c|c|c|c|c|}
\hline \multirow{3}{*}{ Trekking } & 9 & 8 & 7 & 6 & 5 & 4 & 3 & 2 & $\mathbf{1}$ & 2 & 3 & 4 & 5 & 6 & 7 & 8 & 9 & Bird/butterfly watching \\
\cline { 2 - 12 } & 9 & 8 & 7 & 6 & 5 & 4 & 3 & 2 & $\mathbf{1}$ & 2 & 3 & 4 & 5 & 6 & 7 & 8 & 9 & Photo safari \\
\cline { 2 - 12 } & 9 & 8 & 7 & 6 & 5 & 4 & 3 & 2 & $\mathbf{1}$ & 2 & 3 & 4 & 5 & 6 & 7 & 8 & 9 & Bicycle safari \\
\hline
\end{tabular}

Bird/butterfly watching

\begin{tabular}{|c|c|c|c|c|c|c|c|c|c|c|c|}
\hline 9 & \begin{tabular}{l|l}
8 & 7 \\
\end{tabular} & 6 & \begin{tabular}{l|l}
5 & 4 \\
\end{tabular} & $\begin{array}{llll}4 & 3 & 2 \\
\end{array}$ & \begin{tabular}{|l|l|}
2 & 1 \\
\end{tabular} & 23 & \begin{tabular}{|l|l|}
3 & 4 \\
\end{tabular} & \begin{tabular}{|l|l|}
5 & 6 \\
\end{tabular} & \begin{tabular}{|l|l|}
6 & 7 \\
\end{tabular} & \begin{tabular}{|l|l}
8 & 5 \\
\end{tabular} & Photo safari \\
\hline 9 & \begin{tabular}{l|l}
8 & 7
\end{tabular} & 6 & \begin{tabular}{l|l}
5 & 4 \\
\end{tabular} & $4|3| 2$ & \begin{tabular}{|l|l|}
2 & 1
\end{tabular} & & & & & \begin{tabular}{|l|c|c}
8 & 5
\end{tabular} & Bicycle safar \\
\hline
\end{tabular}

Photo safari

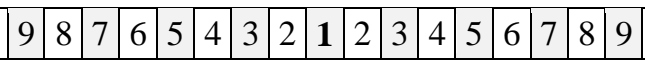

Bicycle safari

3- What is the relative importance of the following activities related to demographic structure of visitors sub-factors in order to determine the most suitable ecotourism activity according to the existing potentials?

\begin{tabular}{|c|c|c|c|c|c|c|c|c|c|c|c|c|c|c|}
\hline \multirow{4}{*}{ Botanical tourism } & 9 & 877 & 76 & 5 & 4 & 3 & \begin{tabular}{l|l}
2 & 1 \\
\end{tabular} & 12 & 3 & 4 & $5 \mid 6$ & \begin{tabular}{l|l}
6 & 7
\end{tabular} & \begin{tabular}{|l|l}
8 & 9 \\
\end{tabular} & Trekking \\
\hline & 9 & \begin{tabular}{l|l}
8 & 7 \\
7
\end{tabular} & 76 & 5 & 4 & 3 & \begin{tabular}{l|l}
2 & 1
\end{tabular} & 2 & 3 & 4 & 5 & \begin{tabular}{l|l|l}
6 & 7
\end{tabular} & 89 & Bird/butterfly watching \\
\hline & 9 & 87 & 76 & 5 & 4 & 3 & 21 & 2 & 3 & 4 & & \begin{tabular}{l|l}
6 & 7
\end{tabular} & 89 & Photo safari \\
\hline & 9 & 8 . & 76 & 5 & 4 & 3 & 21 & 2 & 3 & 4 & 5 & $\begin{array}{ll}6 & 7\end{array}$ & 89 & Bicycle safari \\
\hline
\end{tabular}




\begin{tabular}{|c|c|c|c|c|c|c|c|c|c|c|c|c|c|}
\hline \multirow{3}{*}{ Trekking } & \begin{tabular}{l|l}
9 & 8 \\
\end{tabular} & 7 & 65 & \begin{tabular}{l|l|l}
5 & 4 \\
\end{tabular} & 3 & \begin{tabular}{l|l}
2 & 1 \\
\end{tabular} & 2 & & 4 & & 7 & 8 & Bird/butterfly watching \\
\hline & \begin{tabular}{|l|l}
9 & 8 \\
$r$
\end{tabular} & 7 & $6 \mid 5$ & \begin{tabular}{l|l|l}
5 & 4
\end{tabular} & 3 & $2 \mid 1$ & 2 & & 4 & & 7 & 8 & Photo safari \\
\hline & & & 6 & \begin{tabular}{l|l}
5 & 4
\end{tabular} & & & 12 & & 4 & & 7 & 8 & Bicycle safari \\
\hline
\end{tabular}

Bird/butterfly watching

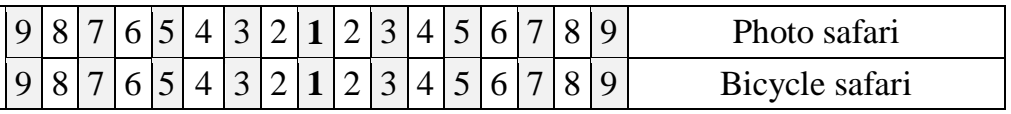

Photo safari

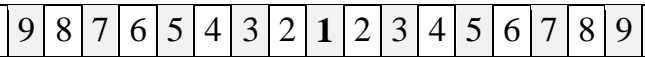

Bicycle safari

4- What is the relative importance of the following activities related to existence of nearby attraction centres sub-factors in order to determine the most suitable ecotourism activity according to the existing potentials?

\begin{tabular}{|c|c|c|c|c|c|c|c|c|c|c|c|c|c|c|c|}
\hline \multirow{4}{*}{ Botanical tourism } & 9 & 8 & 7 & \begin{tabular}{l|l}
6 & 5
\end{tabular} & 4 & 3 & 2 & 12 & 3 & 4 & 5 & \begin{tabular}{|l|l}
6 & 7 \\
\end{tabular} & & 9 & Trekking \\
\hline & 9 & 8 & 7 ( & 65 & 4 & 3 & 2 & 12 & 2 & 4 & 5 & \begin{tabular}{|l|l}
6 & 7 \\
\end{tabular} & 78 & 9 & Bird/butterfly watching \\
\hline & 9 & 8 & 7 ( & \begin{tabular}{l|l}
6 & 5
\end{tabular} & 4 & 3 & 2 & 12 & 3 & 4 & 5 & \begin{tabular}{|l|l}
6 & 7 \\
\end{tabular} & 78 & 9 & Photo safari \\
\hline & 9 & 8 & $7 \mid$ & \begin{tabular}{l|l}
6 & 5 \\
\end{tabular} & 4 & 3 & 2 & 12 & 3 & 4 & & \begin{tabular}{|l|l|}
6 & 7 \\
\end{tabular} & \begin{tabular}{l|l}
7 & 8 \\
\end{tabular} & 9 & Bicycle safari \\
\hline \multirow{3}{*}{ Trekking } & 9 & 8 & 76 & 65 & 4 & & 2 & 2 & & 4 & 5 & 67 & & 9 & Bird/butterfly watching \\
\hline & 9 & 8 & 76 & $6 \sqrt{6}$ & 4 & 3 & 2 & 12 & 3 & 4 & 5 & \begin{tabular}{|l|l}
6 & 7 \\
\end{tabular} & 78 & 9 & Photo safari \\
\hline & \begin{tabular}{|c|}
9 \\
\end{tabular} & 8 & 76 & \begin{tabular}{l|l}
6 & 5
\end{tabular} & 4 & 3 & 2 & 12 & 3 & 4 & 5 & \begin{tabular}{l|l}
6 & 7 \\
\end{tabular} & $7 \longdiv { 8 }$ & 9 & Bicycle safari \\
\hline
\end{tabular}

Bird/butterfly watching

\begin{tabular}{|l|l|l|l|l|l|l|l|l|l|l|l|l|l|l|l|l|l|}
9 & 8 & 7 & 6 & 5 & 4 & 3 & 2 & $\mathbf{1}$ & 2 & 3 & 4 & 5 & 6 & 7 & 8 & 9 & Photo safari \\
\hline 9 & 8 & 7 & 6 & 5 & 4 & 3 & 2 & $\mathbf{1}$ & 2 & 3 & 4 & 5 & 6 & 7 & 8 & 9 & Bicycle safari \\
\hline
\end{tabular}

Photo safari

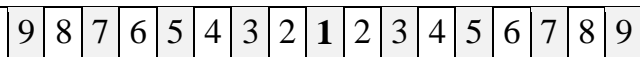

Bicycle safari

\section{Relevant importance of ecotourism activities according to the sub-criteria of the field use targets criteria}

1- What is the relative importance of the following activities related to biodiversity conservation sub-factors in order to determine the most suitable ecotourism activity according to the existing potentials?

\begin{tabular}{|c|c|c|c|c|c|c|c|c|c|c|c|c|c|c|c|}
\hline \multirow{4}{*}{ Botanical tourism } & 9 & 8 & $7 \mid$ & 65 & 4 & 3 & 2 & 12 & 23 & 4 & 5 & 6 & $7 \mid 8=28$ & 39 & Trekking \\
\hline & 9 & 8 & 7 & 65 & 4 & 3 & 2 & 12 & 23 & 4 & 5 & 6 & 7 \& & 39 & Bird/butterfly watching \\
\hline & 9 & 8 & 7 & $\begin{array}{l}6 \\
6\end{array}$ & 4 & 3 & 2 & 12 & 23 & 4 & 5 & 6 & $7 \mid 8$ & 39 & Photo safari \\
\hline & 9 & 8 & 7 & 65 & 4 & 3 & 2 & 12 & 23 & 4 & 5 & 6 & \begin{tabular}{l|l}
7 & $\varepsilon$ \\
\end{tabular} & 39 & Bicycle safari \\
\hline \multirow{4}{*}{ Trekking } & & & & & & & & & & & & & & & \\
\hline & 9 & 8 & 76 & 65 & 4 & 3 & 2 & 12 & 3 & 4 & 5 & $6{ }^{7}$ & 78 & 9 & Bird/butterfly watching \\
\hline & 9 & 8 & 76 & 65 & 4 & 3 & 2 & 12 & 3 & 4 & 5 & 6 & 78 & 9 & Photo safari \\
\hline & 9 & 8 & 7 & \begin{tabular}{l|l}
6 & 5
\end{tabular} & 4 & 3 & 2 & 12 & 3 & 4 & 5 & & & 9 & Bicycle safari \\
\hline
\end{tabular}

Bird/butterfly watching

\begin{tabular}{|l|l|l|l|l|l|l|l|l|l|l|l|l|l|l|l|l|c|}
\hline 9 & 8 & 7 & 6 & 5 & 4 & 3 & 2 & $\mathbf{1}$ & 2 & 3 & 4 & 5 & 6 & 7 & 8 & 9 & Photo safari \\
\hline 9 & 8 & 7 & 6 & 5 & 4 & 3 & 2 & $\mathbf{1}$ & 2 & 3 & 4 & 5 & 6 & 7 & 8 & 9 & Bicycle safari \\
\hline
\end{tabular}


2- What is the relative importance of the following activities related to satisfaction of recreational needs sub-factors in order to determine the most suitable ecotourism activity according to the existing potentials?

\begin{tabular}{|l|l|l|l|l|l|l|l|l|l|l|l|l|l|l|l|l|l|c|}
\hline \multirow{3}{*}{ Botanical tourism } & 9 & 8 & 7 & 6 & 5 & 4 & 3 & 2 & $\mathbf{1}$ & 2 & 3 & 4 & 5 & 6 & 7 & 8 & 9 & Trekking \\
\cline { 2 - 13 } & 9 & 8 & 7 & 6 & 5 & 4 & 3 & 2 & $\mathbf{1}$ & 2 & 3 & 4 & 5 & 6 & 7 & 8 & 9 & Bird/butterfly watching \\
\cline { 2 - 13 } & 9 & 8 & 7 & 6 & 5 & 4 & 3 & 2 & $\mathbf{1}$ & 2 & 3 & 4 & 5 & 6 & 7 & 8 & 9 & Photo safari \\
\cline { 2 - 11 } & 9 & 8 & 7 & 6 & 5 & 4 & 3 & 2 & $\mathbf{1}$ & 2 & 3 & 4 & 5 & 6 & 7 & 8 & 9 & Bicycle safari \\
\hline
\end{tabular}

\begin{tabular}{|c|c|c|c|c|c|c|c|c|c|c|c|c|c|c|c|c|c|}
\hline \multirow{3}{*}{ Trekking } & 9 & 8 & 7 & 6 & 5 & 4 & 3 & 2 & 1 & 2 & & 4 & 5 & 6 & $7 \mid 8$ & 9 & Bird/butterfly watching \\
\hline & 9 & 8 & 7 & 6 & 5 & 4 & 3 & 2 & 1 & 2 & 3 & 4 & 5 & 6 & 7 & 9 & Photo safari \\
\hline & 9 & 8 & 7 & 6 & 5 & 4 & 3 & 2 & 1 & 2 & 3 & 4 & 5 & 6 & $7 \mid 8$ & 9 & Bicycle safari \\
\hline
\end{tabular}

Bird/butterfly watching

\begin{tabular}{|c|c|c|c|c|c|c|c|c|c|c|c|c|c|c|c|c|c|}
9 & 8 & 7 & 6 & 5 & 4 & 3 & 2 & 1 & 2 & 3 & 4 & 5 & 6 & 7 & 8 & 9 & Photo safari \\
\hline 9 & 8 & 7 & 6 & 5 & 4 & 3 & 2 & 1 & 2 & 3 & 4 & 5 & 6 & 7 & 8 & 9 & Bicycle safari \\
\hline
\end{tabular}

Photo safari

\begin{tabular}{|l|l|l|l|l|l|l|l|l|l|l|l|l|l|l|l|l|l}
9 & 8 & 7 & 6 & 5 & 4 & 3 & 2 & 1 & 2 & 3 & 4 & 5 & 6 & 7 & 8 & 9 & Bicycle safari
\end{tabular}

3- What is the relative importance of the following activities related to preservation of visual landscape potentials sub-factors in order to determine the most suitable ecotourism activity according to the existing potentials?

\begin{tabular}{|c|c|c|c|c|c|c|c|c|c|c|c|c|c|c|c|c|c|c|}
\hline \multirow{3}{*}{ Botanical tourism } & 9 & 8 & 7 & 6 & 5 & 4 & 3 & 2 & 1 & 2 & 3 & 4 & 5 & 6 & 7 & 8 & 9 & Trekking \\
\cline { 2 - 12 } & 9 & 8 & 7 & 6 & 5 & 4 & 3 & 2 & 1 & 2 & 3 & 4 & 5 & 6 & 7 & 8 & 9 & Bird/butterfly watching \\
\cline { 2 - 12 } & 9 & 8 & 7 & 6 & 5 & 4 & 3 & 2 & 1 & 2 & 3 & 4 & 5 & 6 & 7 & 8 & 9 & Photo safari \\
\cline { 2 - 11 } & 9 & 8 & 7 & 6 & 5 & 4 & 3 & 2 & 1 & 2 & 3 & 4 & 5 & 6 & 7 & 8 & 9 & Bicycle safari \\
\hline
\end{tabular}

\begin{tabular}{|c|c|c|c|c|c|c|c|c|c|c|c|c|c|c|c|c|c|}
\hline \multirow{3}{*}{ Trekking } & 9 & 8 & 7 & 6 & 5 & 4 & 3 & 2 & 1 & 2 & 3 & 4 & 5 & 6 & 78 & $8 \mid 9$ & Bird/butterfly watching \\
\hline & 9 & 8 & 7 & 6 & 5 & 4 & 3 & 2 & 1 & 2 & 3 & 4 & 5 & 6 & 7 & $8 \mid 9$ & Photo safari \\
\hline & 9 & 8 & 7 & 6 & 5 & 4 & 3 & 2 & 1 & 2 & 3 & 4 & 5 & 6 & 78 & $8 \mid 9$ & Bicycle safari \\
\hline
\end{tabular}

Bird/butterfly watching

\begin{tabular}{|l|l|l|l|l|l|l|l|l|l|l|l|l|l|l|l|l|l|}
9 & 8 & 7 & 6 & 5 & 4 & 3 & 2 & $\mathbf{1}$ & 2 & 3 & 4 & 5 & 6 & 7 & 8 & 9 & Photo safari \\
\hline 9 & 8 & 7 & 6 & 5 & 4 & 3 & 2 & $\mathbf{1}$ & 2 & 3 & 4 & 5 & 6 & 7 & 8 & 9 & Bicycle safari \\
\hline
\end{tabular}

Photo safari

\begin{tabular}{|l|l|l|l|l|l|l|l|l|l|l|l|l|l|l|l|l|}
9 & 8 & 7 & 6 & 5 & 4 & 3 & 2 & $\mathbf{1}$ & 2 & 3 & 4 & 5 & 6 & 7 & 8 & 9 \\
\hline
\end{tabular}

Bicycle safari

4- What is the relative importance of the following activities related to city branding subfactors in order to determine the most suitable ecotourism activity according to the existing potentials?

\begin{tabular}{|c|c|c|c|c|c|c|c|c|c|c|c|c|c|c|c|c|}
\hline \multirow{4}{*}{ Botanical tourism } & 9 & 8 & 7 & 6 & 5 & 4 & 3 & 2 & 12 & 23 & 4 & 5 & 6 & 78 & 89 & Trekking \\
\hline & 9 & 8 & 7 & 6 & 5 & 4 & 3 & 2 & \begin{tabular}{l|l}
1 & 2 \\
\end{tabular} & \begin{tabular}{l|l}
2 & 3
\end{tabular} & 4 & 5 & 6 & 78 & \begin{tabular}{l|l}
8 & 9
\end{tabular} & Bird/butterfly watching \\
\hline & 9 & 8 & 7 & 6 & 5 & 4 & 3 & 2 & \begin{tabular}{l|l}
1 & 2 \\
1
\end{tabular} & $2 \mid 3$ & 4 & 5 & 6 & 78 & 89 & Photo safari \\
\hline & 9 & 8 & 7 & 6 & 5 & 4 & 3 & 2 & \begin{tabular}{l|l}
1 & 2 \\
\end{tabular} & \begin{tabular}{l|l}
2 & 3
\end{tabular} & 4 & 5 & 6 & 78 & $8: 9$ & Bicycle safari \\
\hline
\end{tabular}




\begin{tabular}{|c|c|c|c|c|c|c|c|c|c|c|c|c|c|}
\hline \multirow{3}{*}{ Trekking } & 9 & \begin{tabular}{|l|l}
8 & 7 \\
\end{tabular} & 6 & & 4 & & 2 & 3 & 4 & 6 & $7 \mid 7$ & $8 \mid 9$ & Bird/butterfly watching \\
\hline & 9 & \begin{tabular}{l|l}
87 \\
8
\end{tabular} & 6 & \begin{tabular}{c|c}
5 & 4 \\
\end{tabular} & 3 & & 12 & 3 & 4 & 56 & 7 & \begin{tabular}{l|l}
8 & 9
\end{tabular} & Photo safari \\
\hline & 9 & $\begin{array}{ll}87 \\
\end{array}$ & 76 & \begin{tabular}{|l|l}
5 & 4
\end{tabular} & 3 & 2 & 12 & 3 & 45 & \begin{tabular}{|l|l|}
5 & 6
\end{tabular} & 7 & \begin{tabular}{l|l}
8 & 9
\end{tabular} & Bicycle safari \\
\hline
\end{tabular}

Bird/butterfly watching

\begin{tabular}{|c|c|c|c|c|c|c|c|c|c|c|}
\hline 8 & \begin{tabular}{|l|l|}
7 & 6
\end{tabular} & \begin{tabular}{|l|l|l}
5 & 5 \\
\end{tabular} & \begin{tabular}{l|l|l}
4 & 3
\end{tabular} & \begin{tabular}{l|l|l|}
2 & 1 &
\end{tabular} & \begin{tabular}{|l|l}
2 & 3
\end{tabular} & 4 & \begin{tabular}{l|l}
5 & 6
\end{tabular} & 57 & 8 & Photo safari \\
\hline \begin{tabular}{|l|l|}
9 & 8 \\
\end{tabular} & & & & & & \begin{tabular}{|l|l|}
3 & 4 \\
\end{tabular} & & & 8 & le safari \\
\hline
\end{tabular}

Photo safari

\begin{tabular}{l|l|l|l|l|l|l|l|l|l|l|l|l|l|l|l|l|}
9 & 8 & 7 & 6 & 5 & 4 & 3 & 2 & $\mathbf{1}$ & 2 & 3 & 4 & 5 & 6 & 7 & 8 & 9 \\
\hline
\end{tabular}

Bicycle safari

5- What is the relative importance of the following activities related to diversification of tourism activities sub-factors in order to determine the most suitable ecotourism activity according to the existing potentials?

\begin{tabular}{|c|c|c|c|c|c|c|c|c|c|c|c|c|c|c|}
\hline \multirow{4}{*}{ Botanical tourism } & \begin{tabular}{l|l}
9 & 8 \\
\end{tabular} & \begin{tabular}{l|l|l|}
8 & 7
\end{tabular} & $6 \mid 5$ & 5 & 3 & 2 & 1 & 3 & 4 & 5 & 57 & & 9 & Trekking \\
\hline & 98 & \begin{tabular}{l|l|}
8 & 7 \\
\end{tabular} & 65 & 54 & 3 & 2 & 12 & 3 & 4 & 5 & 6 & & 9 & Bird/butterfly watching \\
\hline & \begin{tabular}{l|l}
9 & 8 \\
\end{tabular} & \begin{tabular}{l|l|l}
8 & 7 \\
\end{tabular} & 65 & \begin{tabular}{|l|l|}
5 & 4 \\
\end{tabular} & 3 & 2 & 12 & 3 & 4 & 5 & 6 & & 9 & Photo safari \\
\hline & \begin{tabular}{l|l}
9 & 8 \\
\end{tabular} & \begin{tabular}{l|l|l}
8 & 7
\end{tabular} & $6 \mid 5$ & $\begin{array}{l}5 \\
5\end{array}$ & 3 & 2 & 12 & & 4 & 5 & $\begin{array}{l}6 \\
67\end{array}$ & & 9 & Bicycle safari \\
\hline
\end{tabular}

\begin{tabular}{|c|c|c|c|c|c|c|c|c|c|c|c|c|c|c|c|c|c|c|}
\hline \multirow{3}{*}{ Trekking } & 9 & 8 & 7 & 6 & 5 & 4 & 3 & 2 & $\mathbf{1}$ & 2 & 3 & 4 & 5 & 6 & 7 & 8 & 9 & Bird/butterfly watching \\
\cline { 2 - 12 } & 9 & 8 & 7 & 6 & 5 & 4 & 3 & 2 & $\mathbf{1}$ & 2 & 3 & 4 & 5 & 6 & 7 & 8 & 9 & Photo safari \\
\cline { 2 - 12 } & 9 & 8 & 7 & 6 & 5 & 4 & 3 & 2 & $\mathbf{1}$ & 2 & 3 & 4 & 5 & 6 & 7 & 8 & 9 & Bicycle safari \\
\hline
\end{tabular}

Bird/butterfly watching

\begin{tabular}{|l|l|l|l|l|l|l|l|l|l|l|l|l|l|l|l|l|c|}
\hline & 8 & 7 & 6 & 5 & 4 & 3 & 2 & $\mathbf{1}$ & 2 & 3 & 4 & 5 & 6 & 7 & 8 & 9 & Photo safari \\
\hline 9 & 8 & 7 & 6 & 5 & 4 & 3 & 2 & $\mathbf{1}$ & 2 & 3 & 4 & 5 & 6 & 7 & 8 & 9 & Bicycle safari \\
\hline
\end{tabular}

Photo safari

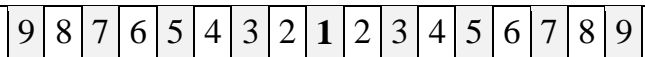

Bicycle safari

6- What is the relative importance of the following activities related to increase in business opportunities sub-factors in order to determine the most suitable ecotourism activity according to the existing potentials?

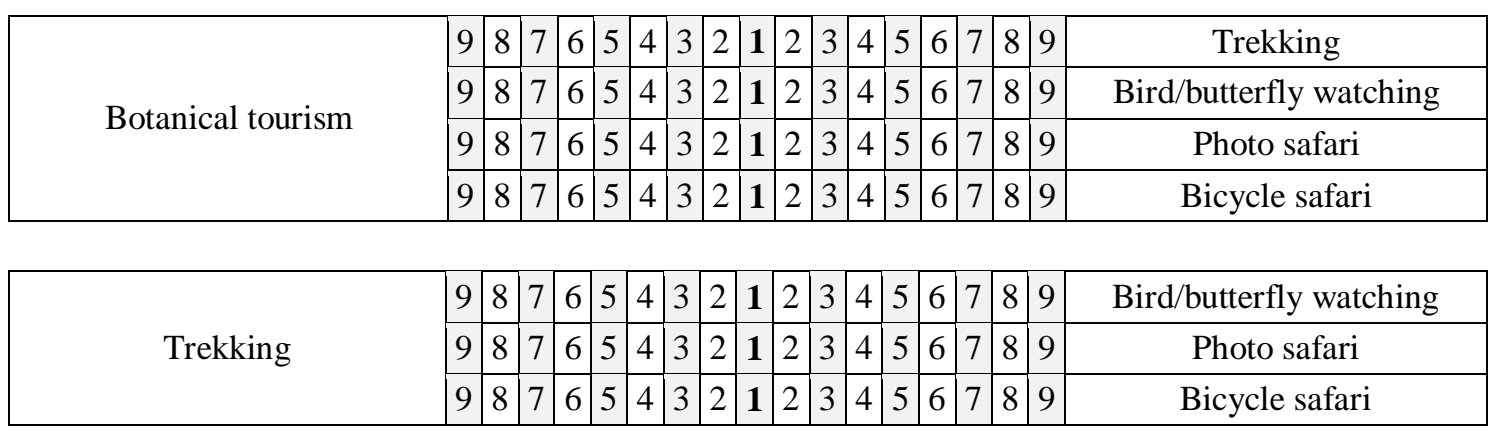

Bird/butterfly watching

\begin{tabular}{|c|c|c|c|c|c|c|c|c|c|c|c|}
\hline 8 & \begin{tabular}{|l|l|l}
7 & 6 \\
\end{tabular} & \begin{tabular}{l|l|}
6 & 5 \\
\end{tabular} & \begin{tabular}{|l|l|}
4 & 3 \\
\end{tabular} & 2 & \begin{tabular}{l|l}
1 & 2 \\
\end{tabular} & 3 & & \begin{tabular}{l|l}
6 & 7 \\
\end{tabular} & 78 & 9 & Photo safari \\
\hline \begin{tabular}{|l|l|}
9 & 8 \\
\end{tabular} & & & \begin{tabular}{|l|l|}
4 & 3 \\
\end{tabular} & \begin{tabular}{l|l|}
32 \\
\end{tabular} & \begin{tabular}{l|l|}
1 & 2 \\
\end{tabular} & & \begin{tabular}{l|l}
4 & 5 \\
\end{tabular} & 67 & & 9 & Bicycle safari \\
\hline
\end{tabular}

Photo safari

\begin{tabular}{l|l|l|l|l|l|l|l|l|l|l|l|l|l|l|l|l|}
9 & 8 & 7 & 6 & 5 & 4 & 3 & 2 & $\mathbf{1}$ & 2 & 3 & 4 & 5 & 6 & 7 & 8 & 9 \\
\hline
\end{tabular}

Bicycle safari 
7- What is the relative importance of the following activities related to improvement of infrastructure sub-factors in order to determine the most suitable ecotourism activity according to the existing potentials?

\begin{tabular}{|c|c|c|c|c|c|c|c|c|c|c|c|c|c|c|}
\hline \multirow{4}{*}{ Botanical tourism } & 9 & \begin{tabular}{l|l|l}
8 & 7
\end{tabular} & 6 & \begin{tabular}{l|l|l}
5 & 4
\end{tabular} & 3 & 2 & \begin{tabular}{l|l}
1 & 2
\end{tabular} & 3 & 4 & & 7 & & 9 & Trekking \\
\hline & 9 & $8 \quad 7$ & $6:$ & \begin{tabular}{l|l}
5 & 4 \\
\end{tabular} & 3 & 2 & 12 & 3 & 4 & & 7 & & 9 & Bird/butterfly watching \\
\hline & 9 & \begin{tabular}{l|l|l}
8 & 7
\end{tabular} & $6:$ & \begin{tabular}{l|l}
5 & 4
\end{tabular} & 3 & 2 & \begin{tabular}{l|l}
1 & 2 \\
r
\end{tabular} & 3 & 4 & & 7 & & 9 & Photo safari \\
\hline & 9 & \begin{tabular}{l|l|l}
8 & 7
\end{tabular} & 65 & \begin{tabular}{l|l}
5 & 4
\end{tabular} & & 2 & \begin{tabular}{l|l}
1 & 2 \\
\end{tabular} & & 4 & & 67 & & 9 & Bicycle safari \\
\hline
\end{tabular}

\begin{tabular}{|c|c|c|c|c|c|c|c|c|c|c|c|c|c|c|}
\hline \multirow{3}{*}{ Trekking } & 9 & 87 & $\begin{array}{ll}7 & 6\end{array}$ & 5 & \begin{tabular}{l|l}
4 & 3
\end{tabular} & 2 & 1 & 23 & 4 & & 6 . & & 9 & Bird/butterfly watching \\
\hline & 9 & 87 & \begin{tabular}{l|l|l|l|l}
7 & 6
\end{tabular} & 5 & \begin{tabular}{l|l}
43 & 3
\end{tabular} & 2 & 1 & 23 & 4 & 5 & 6 - 7 & & 9 & Photo safari \\
\hline & 9 & 87 & \begin{tabular}{l|l}
7 & 6
\end{tabular} & 5 & \begin{tabular}{|l|l|l}
4 & 3
\end{tabular} & 2 & 1 & 233 & 4 & & 6 - 7 & & 9 & Bicycle safari \\
\hline
\end{tabular}

Bird/butterfly watching

\begin{tabular}{|c|c|c|c|c|c|c|c|c|c|c|c|c|}
\hline \begin{tabular}{|l|l}
9 \\
\end{tabular} & \begin{tabular}{l|l|}
8 & 7 \\
\end{tabular} & 65 & \begin{tabular}{l|l}
5 & 4 \\
\end{tabular} & 3 & 21 & \begin{tabular}{l|l}
1 \\
\end{tabular} & 3 & 4 & \begin{tabular}{l|l}
5 & 6 \\
\end{tabular} & 7 & \begin{tabular}{|l|l}
8 & 9 \\
\end{tabular} & Photo safari \\
\hline \begin{tabular}{|l|}
9 \\
\end{tabular} & \begin{tabular}{l|l|}
8 & 7 \\
\end{tabular} & 6 & \begin{tabular}{l|l}
5 & 4 \\
\end{tabular} & 3 & \begin{tabular}{|l|l}
2 & 1 \\
\end{tabular} & $1 \mid 2$ & 23 & 4 & \begin{tabular}{l|l}
5 & 6 \\
\end{tabular} & 7 & \begin{tabular}{l|l}
8 & 9 \\
\end{tabular} & Bicycle safari \\
\hline
\end{tabular}

Photo safari

\begin{tabular}{l|l|l|l|l|l|l|l|l|l|l|l|l|l|l|l|l|}
9 & 8 & 7 & 6 & 5 & 4 & 3 & 2 & $\mathbf{1}$ & 2 & 3 & 4 & 5 & 6 & 7 & 8 & 9
\end{tabular}

Bicycle safari 